\title{
Convenient Methods of Synthesis for a Library of Hemilabile Phosphines
}

\author{
M. Victoria Jiménez, * Jesús J. Pérez-Torrente, M. Isabel Bartolomé and Luis A. Oro \\ Departamento de Química Inorgánica, Instituto Universitario de Catálisis Homogénea-Instituto de Ciencia de Materiales de Aragón,, \\ Universidad de Zaragoza-C.S.I.C., 50009-Zaragoza, Spain. \\ Fax: +34-976-762284; E-mail: vjimenez@unizar.es \\ Received: The date will be inserted once the manuscript is accepted.
}

\begin{abstract}
A series of novel functionalized phosphines of hemilabile character, $\mathrm{R}_{2} \mathrm{P}\left(\mathrm{CH}_{2}\right)_{\mathrm{n}} \mathrm{Z}$, have been prepared from diarylphosphines using several synthetic methodologies. The synthetic methods include the alkylation of lithium diarylphosphide or diarylphosphino-borane adducts with functionalized halogenoalkanes, $\mathrm{X}-\left(\mathrm{CH}_{2}\right)_{\mathrm{n}}-\mathrm{Z}$, and the photochemical hydrophosphination of suitable functionalized allyl or vinyl derivatives, $\mathrm{CH}_{2}=\mathrm{CH}-\mathrm{Z}$ or $\mathrm{CH}_{2}=\mathrm{CH}-\mathrm{CH}_{2}-\mathrm{Z}$, using white light. A range of $\mathrm{R}_{2} \mathrm{PH}\left(\mathrm{R}=\mathrm{C}_{6} \mathrm{H}_{5^{-}}\right.$ $\mathrm{CH}_{2}, \quad p-\mathrm{CH}_{3} \mathrm{O}-\mathrm{C}_{6} \mathrm{H}_{4}, \quad p-\mathrm{CH}_{3}-\mathrm{C}_{6} \mathrm{H}_{4}, o-\mathrm{CH}_{3}-\mathrm{C}_{6} \mathrm{H}_{4}, \mathrm{C}_{6} \mathrm{H}_{5}, p-\mathrm{CF}_{3}-$ $\mathrm{C}_{6} \mathrm{H}_{4}$ ) has been used in order to tune the electronic density on the $\mathrm{P}$ donor atom. The coordination ability of the hemilabile fragment was modified by selection of the donor group $(\mathrm{Z}=\mathrm{OMe}, \mathrm{OEt}, \mathrm{O} n$ $\left.\mathrm{Bu}, \mathrm{NMe}_{2}\right)$ or the length of the flexible carbon chain $(\mathrm{n}=2,3)$. Hemilabile fluorinated allyl phosphines, $\mathrm{R}_{2} \mathrm{PCH}_{2} \mathrm{CH}=\mathrm{CH}_{2}(\mathrm{R}=p$ $\mathrm{F}-\mathrm{C}_{6} \mathrm{H}_{4}, \mathrm{C}_{6} \mathrm{~F}_{5}$ ), have been prepared from diarylchlorophosphines and allymagnesiun bromide.
\end{abstract}

Key words: hemilabile ligands, functionalized phosphines, hydrophosphination.

Catalytic activity in transition metal catalyzed reactions is strongly affected by the electronic and steric characteristics of the coordinated ligands to the metallic centre. In fact, this influence has found application in the "fine tuning" of the catalyst properties. At the same time, it is desirable that the ligands are able to furnish open coordination sites and stabilize reactive transition metal species during the course of the catalysis. Actually, this reversible protection of one or more coordination sites is the most important property of hemilabile ligands.

The concept of hemilability was first introduced by Rauchfuss referring to the labile coordination of some ligands bearing electronically divergent soft and hard donor atoms. ${ }^{1}$ These hemilabile ligands and their coordination chemistry have received increased interest in recent years. In general, with late transition metals, the hard donor centre is only weekly coordinated to the metal center and allows -by decoordination- the binding of substrates that induce ulterior reactivity. Metal complexes containing hemilabile ligands have been found to be active in a range of catalytic reactions, including hydrogenation, hydrosilylation, carbonylation, hydroformylation, allylation, epoxydation, olefin (co)dimerization or copolymerization and ring-opening methathesis polymerization (ROMP). ${ }^{2}$

In this context, functionalized phosphines have been intensively studied ${ }^{3}$ as hemilabile ligands for soft metal centers because of their ability for providing either easily accessible coordination vacancies or protecting the active catalytic site, through a potentially dynamic "on and off" chelating effect for the metal center. Hybrid P,O- ${ }^{2 b, 4}$ and $\mathrm{P}, \mathrm{N}$-based ligands ${ }^{5}$ have been the most investigated since phosphorous usually binds strongly to the metal center whereas the other donor atom $(\mathrm{O}$ or $\mathrm{N})$ is generally only weakly bonded.

We have recently become interested in the design of hemilabile ligands for transition metal catalytic applications. ${ }^{6}$ In particular, we have been intensively studying the scope and potential of a series of functionalized phosphines of the type $\mathrm{R}_{2} \mathrm{P}\left(\mathrm{CH}_{2}\right)_{\mathrm{n}} \mathrm{Z}$ (Figure 1). Although a number of these phosphines have been described in the literature, ${ }^{7-9}$ we have noticed the lack of well-defined synthetic protocols for the synthesis of a library of hemilabile phosphines that allow the "fine tuning" of the catalytic systems. These ligands offer the potential for the modulation of the electronic density on the $\mathrm{P}$ donor atom by introducing electron donating or withdrawing substituents in the aryl groups of the phosphine fragment, as well as for the control of the coordination ability of the hemilabile fragment by the selection of the donor group (-OR, $-\mathrm{NR}_{2}$ or $\left.-\mathrm{SR}\right)$ or the length of the flexible carbon chain.

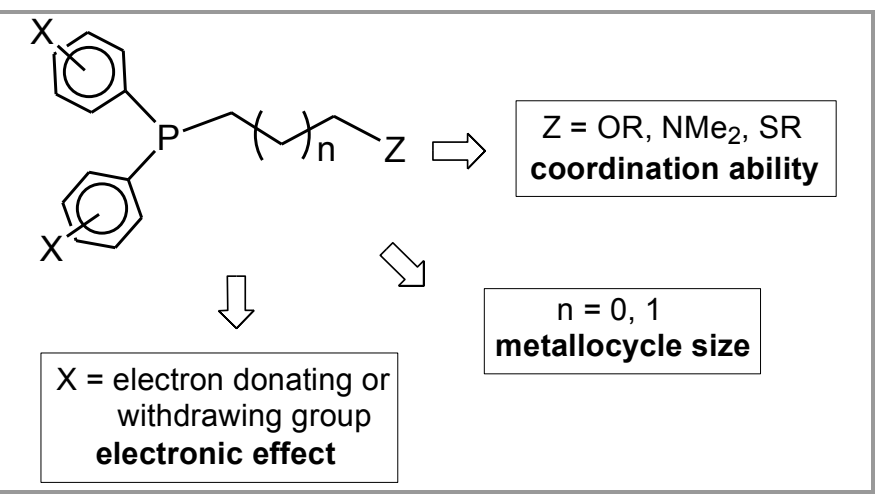

Figure 1

We describe herein the improvement and optimization of synthetic methodologies applied for the successful synthesis of a library of functionalized phosphines $\mathrm{R}_{2} \mathrm{P}\left(\mathrm{CH}_{2}\right)_{\mathrm{n}} \mathrm{Z} \quad\left(\mathrm{R}=\mathrm{C}_{6} \mathrm{H}_{5}-\mathrm{CH}_{2}, p-\mathrm{CH}_{3} \mathrm{O}-\mathrm{C}_{6} \mathrm{H}_{4}, p-\mathrm{CH}_{3}-\right.$ $\mathrm{C}_{6} \mathrm{H}_{4}, o-\mathrm{CH}_{3}-\mathrm{C}_{6} \mathrm{H}_{4}, \mathrm{C}_{6} \mathrm{H}_{5}, p-\mathrm{CF}_{3}-\mathrm{C}_{6} \mathrm{H}_{4} ; \mathrm{n}=2,3 ; \mathrm{Z}=$ $\mathrm{OMe}, \mathrm{OEt}, \mathrm{O} n-\mathrm{Bu}, \mathrm{NMe}_{2}$ ). In addition, the synthesis of potentially hemilabile fluorinated allyl phosphines, $\mathrm{R}_{2} \mathrm{PCH}_{2} \mathrm{CH}=\mathrm{CH}_{2}\left(\mathrm{R}=p-\mathrm{F}-\mathrm{C}_{6} \mathrm{H}_{4}, \mathrm{C}_{6} \mathrm{~F}_{5}\right)$ is also described.

The synthesis of functionalized phosphines, $\mathrm{R}_{2} \mathrm{P}\left(\mathrm{CH}_{2}\right)_{\mathrm{n}} \mathrm{Z}$, can be easily accomplished from diarylphosphine $\left(\mathrm{R}_{2} \mathrm{PH}\right)$ or chlorodiarylphosphine $\left(\mathrm{R}_{2} \mathrm{PCl}\right)$ derivatives. Diphenylphosphine $\left(\mathrm{Ph}_{2} \mathrm{PH}\right)$ is commercial and different strategies have been developed for the synthesis of diaryl(alkyl)phosphine $\left(\mathrm{R}_{2} \mathrm{PH}\right)$ compounds. However, 
from a practical point of view, the synthetic protocols outlined in Schemes 1 and 2 are the more efficient.

Scheme 1 describes the traditional time-consuming laborious method of alkylation/arylation of aminodichlorophophines with Grignard reagents, ${ }^{10}$ and the Scheme 2 outlines the alkylation/arylation of diethylphosphonate ${ }^{11}$ and ulterior reduction of the formed phosphine oxides following recently reported methods.

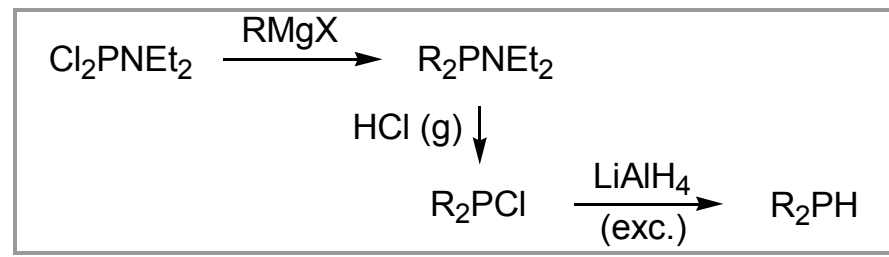

Scheme 1

Although most of diaryl(alkyl)phosphines used in this work were prepared for both methods, the synthesis through phosphine oxides intermediates usually provides higher yields. In fact, the ethoxy groups of diethyl phophonate $(\mathrm{EtO})_{2} \mathrm{P}(\mathrm{O}) \mathrm{H}$ are easily substituted by a variety of alkyl/aryl groups using the corresponding Grignard reagents. Besides, the resulting phosphine oxides are efficiently reduced by using a methylation reagent, as for example methyl iodide or methyl trifluoromethanesulfonate, and a powerful reducing reagent, as lithium aluminum hydride, following the procedure described by Imamoto et al. ${ }^{12}$ In addition, $(\mathrm{EtO})_{2} \mathrm{P}(\mathrm{O}) \mathrm{H}$ is commercially available and easy to handle.

\begin{tabular}{|c|c|c|c|}
\hline$\stackrel{\stackrel{\mathrm{O}}{\mathrm{II}_{2}}{ }_{2} \mathrm{PH}}{\mathrm{PH}}$ & $\mathrm{RMgX}$ & $\stackrel{\mathrm{O}}{\mathrm{R}_{2} \mathrm{PH}}$ & a) $\mathrm{CH}_{3} \mathrm{I}, \mathrm{DME}$ \\
\hline
\end{tabular}

Scheme 2

The synthesis of functionalized phosphines, $\mathrm{R}_{2} \mathrm{P}\left(\mathrm{CH}_{2}\right)_{n} \mathrm{Z}$, have been carried out following three different procedures that involve the alkylation of $\mathrm{LiPR}_{2}$ or phospineborane adducts (methods 1 and 2), and the photochemical hydrophosphination of appropriate unsaturated compounds (method 3). Method 4 provides access to potentially hemilabile fluorinated allylphosphines $\mathrm{R}_{2} \mathrm{PCH}_{2} \mathrm{CH}=\mathrm{CH}_{2}$.

Alkylation of LiPR $($ Method 1). The nucleophilic substitution on functionalized halogenoalkanes $\mathrm{X}\left(\mathrm{CH}_{2}\right)_{\mathrm{n}} \mathrm{Z}$ derivatives by $\mathrm{LiPR}_{2}$ is a convenient entry to functionalized phosphines of the type $\mathrm{R}_{2} \mathrm{P}\left(\mathrm{CH}_{2}\right)_{\mathrm{n}} \mathrm{Z}$ (Scheme 3 ) as it was described by McEwen et al., ${ }^{7}$ Anderson et al. ${ }^{8}$ and Werner et al. ${ }^{9}$

$\mathrm{R}_{2} \mathrm{PH} \stackrel{n-\mathrm{BuLi}}{\longrightarrow} \mathrm{LiPR}_{2} \stackrel{\mathrm{X}\left(\mathrm{CH}_{2}\right)_{n}-\mathrm{Z}}{\longrightarrow} \mathrm{R}_{2} \mathrm{P}\left(\mathrm{CH}_{2}\right)_{\mathrm{n}} \mathrm{Z}$

Scheme 3
A slightly modified version of this synthetic protocol has been applied for the preparation of a range of functionalized phosphines that include: $\mathrm{Ph}_{2} \mathrm{P}\left(\mathrm{CH}_{2}\right)_{2} \mathrm{OMe}$ (1), $\mathrm{Ph}_{2} \mathrm{P}\left(\mathrm{CH}_{2}\right)_{2} \mathrm{NMe}_{2}$ (2), $\mathrm{Ph}_{2} \mathrm{P}\left(\mathrm{CH}_{2}\right)_{3} \mathrm{NMe}_{2}$ (3), $\mathrm{Ph}_{2} \mathrm{P}\left(\mathrm{CH}_{2}\right)_{2}$ SMe (4), $\mathrm{Ph}_{2} \mathrm{P}\left(\mathrm{CH}_{2}\right) \mathrm{SMe}(5), \mathrm{Ph}_{2} \mathrm{P}\left(\mathrm{CH}_{2}\right)_{3} \mathrm{OMe}(\mathbf{6})$, $i$ $\mathrm{Pr}_{2} \mathrm{P}\left(\mathrm{CH}_{2}\right)_{2} \mathrm{OMe}(7),\left(\mathrm{C}_{6} \mathrm{H}_{5}-\mathrm{CH}_{2}\right)_{2} \mathrm{P}\left(\mathrm{CH}_{2}\right)_{2} \mathrm{OMe}(\mathbf{8}),(p-$ $\left.\mathrm{CH}_{3}-\mathrm{C}_{6} \mathrm{H}_{4}\right)_{2} \mathrm{P}\left(\mathrm{CH}_{2}\right)_{2} \mathrm{OMe}$ (9) and $\left(o-\mathrm{CH}_{3}-\mathrm{C}_{6} \mathrm{H}_{4}\right)_{2}$ $\mathrm{P}\left(\mathrm{CH}_{2}\right)_{2} \mathrm{OMe}$ (10). In particular, diphenylphosphine derivatives $\mathbf{1}-\mathbf{5}$ were prepared using commercial $\mathrm{KPPh}_{2}$ solutions in THF. The phosphines were isolated as colorless or pale yellow oils after distillation under reduced pressure, except 5 that was isolated as a white solid. Phosphines 1 - 7 were characterized by comparison of the ${ }^{1} \mathrm{H}$ and ${ }^{31} \mathrm{P}\left\{{ }^{1} \mathrm{H}\right\}$ NMR spectra with the NMR data previously reported in the literature. Interestingly, compound $\mathrm{Ph}_{2} \mathrm{P}\left(\mathrm{CH}_{2}\right)_{3} \mathrm{OMe}(6)$ had previously been synthesized in lower yield by reaction of chlorodiphenylphosphine with $\mathrm{MeO}\left(\mathrm{CH}_{2}\right)_{3} \mathrm{MgCl}^{7 \mathrm{a}}$

The synthesis of the new phosphines $\left(\mathrm{C}_{6} \mathrm{H}_{5}\right.$ $\left.\mathrm{CH}_{2}\right)_{2} \mathrm{P}\left(\mathrm{CH}_{2}\right)_{2} \mathrm{OMe}(\mathbf{8}),\left(p-\mathrm{CH}_{3}-\mathrm{C}_{6} \mathrm{H}_{4}\right)_{2} \mathrm{P}\left(\mathrm{CH}_{2}\right)_{2} \mathrm{OMe}(\mathbf{9})$, and $\left(o-\mathrm{CH}_{3}-\mathrm{C}_{6} \mathrm{H}_{4}\right)_{2} \mathrm{P}\left(\mathrm{CH}_{2}\right)_{2} \mathrm{OMe}(\mathbf{1 0})$, required the previous preparation of $\left(\mathrm{C}_{6} \mathrm{H}_{5}-\mathrm{CH}_{2}\right)_{2} \mathrm{PH},\left(p-\mathrm{CH}_{3}-\mathrm{C}_{6} \mathrm{H}_{4}\right)_{2} \mathrm{PH}$, and $\left(o-\mathrm{CH}_{3}-\mathrm{C}_{6} \mathrm{H}_{4}\right)_{2} \mathrm{PH}$, which was accomplished following the procedure outlined in Scheme 2. Compounds 8 10 have been characterized by elemental analysis, mass spectrometry, and ${ }^{1} \mathrm{H},{ }^{31} \mathrm{P}\left\{{ }^{1} \mathrm{H}\right\},{ }^{13} \mathrm{C}\left\{{ }^{1} \mathrm{H}\right\}$ NMR spectroscopy (see experimental section). In particular, the ${ }^{31} \mathrm{P}\left\{{ }^{1} \mathrm{H}\right\}$ NMR spectra showed a singlet at $\delta-21.84(8)$, 24.60 (9), and -43.97 (10) ppm. The methylene protons of the 2-methoxyethyl fragment were observed as a doublet of triplets $\left(\mathrm{O}-\mathrm{CH}_{2}\right)$ and triplet $\left(\mathrm{P}-\mathrm{CH}_{2}\right)$ between $\delta$ $3.8-3.5$ and $2.4-1.7 \mathrm{ppm}$, respectively, whereas that the methoxy group was observed as a singlet around 3 ppm.

Alkylation of $\mathbf{R}_{\mathbf{2}}\left(\mathrm{BH}_{3}\right) \mathbf{P H}$ under phase-transfer catalysis (Method 2). The oxygen-sensitive nature of phosphines sometimes requires their protection during different synthetic steps. Phosphine-borane complexes have proved to be stable under a variety of reaction conditions and this, makes borane a versatile protecting group widely used in phosphine synthesis. ${ }^{13}$

The alkylation of borane adducts of secondary phosphines by electrophiles in a biphasic solution in the presence of tetrabutylamonium bromide as phase-transfer catalyst, Scheme 4 , is also a convenient method that avoid the use of strong bases. ${ }^{14}$ Although this methodology requires the formation of phosphine-borane adducts and the posterior deprotection of the resulting products, this method is very appropriate for the synthesis of particularly air-sensitive phosphines. In fact, the functionalized phosphines $\mathbf{8}-\mathbf{1 0}$ have been prepared in excellent yields (higher than $80 \%$ ) directly from the secondary phosphines using this procedure without the necessity of isolation and purification of some intermediate products.

The deprotection of the functionalized phosphine-borane adducts, $\mathrm{R}_{2}\left(\mathrm{BH}_{3}\right) \mathrm{P}\left(\mathrm{CH}_{2}\right)_{\mathrm{n}} \mathrm{Z}$, can be accomplished following different procedures using acids or amines. However, we have obtained better yields by using tetrafluoroboric 
acid followed by neutralisation with potasium carbonate. $^{15}$

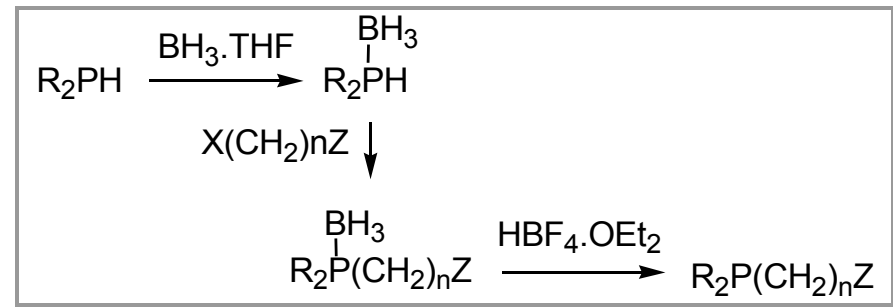

Scheme 4

Photochemical Hydrophosphination of Unsaturated Compounds (Method 3). The hydrophosphination of unsaturated compounds under photochemical conditions has been successfully applied to the synthesis of diphosphine ligands having alcoxyethyl pendant arms by Lindner et al., ${ }^{16}$ or in the preparation of phosphinoalkylsilanes by Stobart et al. ${ }^{17}$

We have found that functionalized allyl or vinyl derivatives are photochemically hydrophosphinated in an efficient and regioselective way to give exclusively the antiMarkonikov products (Scheme 5). This procedure has a wide scope in the synthesis of functionalized phosphine ligands. Thus, diverse unsaturated fragment as vinylethers $\left(\mathrm{CH}_{2}=\mathrm{CH}-\mathrm{OR}, \mathrm{R}=\mathrm{Me}, \mathrm{Et}\right)$, allyl ethers $\left(\mathrm{CH}_{2}=\mathrm{CH}\right.$ $\left.\mathrm{CH}_{2}-\mathrm{OR}, \mathrm{R}=\mathrm{Me}, \mathrm{Et}, n-\mathrm{Bu}\right)$ or allyamine $\left(\mathrm{CH}_{2}=\mathrm{CH}-\right.$ $\mathrm{CH}_{2}-\mathrm{NMe}_{2}$ ) derivatives have been effectively hydrophosphinated with several diarylphosphines $\left(\mathrm{R}_{2} \mathrm{PH}\right)$. The reactions were conducted with an excess of unsaturated vinyl or allyl derivative and, interestingly, without ultraviolet lamps or catalysts, because only visible light from standard white lamps was necessary to drive the reactions to completion. This procedure is very convenient since the reactions, as monitored by ${ }^{31} \mathrm{P}\left\{{ }^{1} \mathrm{H}\right\}$ NMR spectroscopy, are quantitative with no by-products formation. In fact, the phosphines were directly obtained as colorless oils in high yields without the need of further purification by simple removing the excess of olefin in vacuum.

$$
\mathrm{R}_{2} \mathrm{PH} \underset{\mathrm{h} v}{\stackrel{\mathrm{CH}_{2}=\mathrm{CH}-\left(\mathrm{CH}_{2}\right)_{n} \mathrm{Z}}{\longrightarrow}} \mathrm{R}_{2} \mathrm{P}\left(\mathrm{CH}_{2}\right)_{(\mathrm{n}+2)} \mathrm{Z}
$$

Scheme 5

The following phosphines $\left(p-\mathrm{CH}_{3}-\mathrm{C}_{6} \mathrm{H}_{4}\right)_{2} \mathrm{P}\left(\mathrm{CH}_{2}\right)_{2} \mathrm{OEt}$ (11), $\mathrm{Ph}_{2} \mathrm{P}\left(\mathrm{CH}_{2}\right)_{3} \mathrm{OEt}(12), \mathrm{Ph}_{2} \mathrm{P}\left(\mathrm{CH}_{2}\right)_{3} \mathrm{O} n$ - $\mathrm{Bu}$ (13), ( $p$ $\left.\mathrm{CH}_{3}-\mathrm{C}_{6} \mathrm{H}_{4}\right)_{2} \mathrm{P}\left(\mathrm{CH}_{2}\right)_{3} \mathrm{OMe} \quad(\mathbf{1 4}), \quad\left(p-\mathrm{CH}_{3}-\mathrm{C}_{6} \mathrm{H}_{4}\right)_{2-}$ $\mathrm{P}\left(\mathrm{CH}_{2}\right)_{3} \mathrm{OEt}(\mathbf{1 5}),\left(p-\mathrm{CH}_{3}-\mathrm{C}_{6} \mathrm{H}_{4}\right)_{2} \mathrm{P}\left(\mathrm{CH}_{2}\right)_{3} \mathrm{NMe}_{2}(\mathbf{1 6}),(p-$ $\left.\mathrm{CH}_{3} \mathrm{O}-\mathrm{C}_{6} \mathrm{H}_{4}\right)_{2} \mathrm{P}\left(\mathrm{CH}_{2}\right)_{3} \mathrm{OMe} \quad(\mathbf{1 7}), \quad\left(p-\mathrm{CH}_{3} \mathrm{O}-\mathrm{C}_{6} \mathrm{H}_{4}\right)_{2}$ $\mathrm{P}\left(\mathrm{CH}_{2}\right)_{3} \mathrm{OEt}$ (18), and, $\left(p-\mathrm{CH}_{3} \mathrm{O}-\mathrm{C}_{6} \mathrm{H}_{4}\right)_{2} \mathrm{P}\left(\mathrm{CH}_{2}\right)_{3} \mathrm{NMe}_{2}$ (19) have been prepared in excellent yields following this photochemical procedure. This method is particularly appropriate for the synthesis of $\left(p-\mathrm{CF}_{3}-\right.$ $\left.\mathrm{C}_{6} \mathrm{H}_{4}\right)_{2} \mathrm{P}\left(\mathrm{CH}_{2}\right)_{2} \mathrm{OEt}(\mathbf{2 0}),\left(p-\mathrm{CF}_{3}-\mathrm{C}_{6} \mathrm{H}_{4}\right)_{2} \mathrm{P}\left(\mathrm{CH}_{2}\right)_{3} \mathrm{OEt}(\mathbf{2 1})$, and $\left(p-\mathrm{CF}_{3}-\mathrm{C}_{6} \mathrm{H}_{4}\right)_{2} \mathrm{P}\left(\mathrm{CH}_{2}\right)_{3} \mathrm{NMe}_{2} \quad$ (22) because diarylphosphines with fluorinated substituents in the aryl moiety are difficult to deprotonate and consequently, the classical method depicted in Scheme 3 is not applicable. The new phosphines were obtained as air-sensitive colorless oils and characterized by elemental analysis, MS and multinuclear NMR spectroscopy. Interestingly, this method allows the synthesis of phosphines $\mathbf{9}$ and $\mathbf{1 0}$ in higher yields than the obtained with the previously described methods. This methodology has also been adapted for the synthesis of the known phosphine $\mathrm{Ph}_{2} \mathrm{P}\left(\mathrm{CH}_{2}\right)_{2} \mathrm{OEt}(\mathbf{2 2}),{ }^{18}$ which was also obtained in excellent yield.

Preparation of $\mathbf{R}_{\mathbf{2}} \mathbf{P C H} \mathbf{H}_{\mathbf{2}} \mathbf{C H}=\mathbf{C H}_{\mathbf{2}}$ (Method 4): Hybrid phosphine-olefin ligands can work as hemilabile because of the presumed ability to easily dissociate the $\mathrm{C}=\mathrm{C}$ bond. In fact, the hemilabile character of allyldiphenylphosphine ligands is well documented. ${ }^{19}$ We have envisaged the introduction of fluorinated aryl groups on allyldiarylphosphines as a way of enhancing the coordination ability of the olefin side arm by reducing the electronic density on the phosphine fragment.

The synthesis of these fluorinated phosphine ligands has been accomplished from chlorodiarylphosphine derivatives owing to the difficulties to prepare $\mathrm{R}_{2} \mathrm{PLi}$ salts from the corresponding fluorinated diarylphosphines precursors. Thus, the reaction of $\left(p-\mathrm{F}-\mathrm{C}_{6} \mathrm{H}_{4}\right)_{2} \mathrm{PCl}$ or $\left(\mathrm{C}_{6} \mathrm{~F}_{5}\right)_{2} \mathrm{PCl}$ with allylmagnesium bromide (Scheme 6) gave the phosphines $\quad\left(p-\mathrm{F}-\mathrm{C}_{6} \mathrm{H}_{4}\right)_{2} \mathrm{PCH}_{2} \mathrm{CH}=\mathrm{CH}_{2} \quad$ (23), $\left(\mathrm{C}_{6} \mathrm{~F}_{5}\right)_{2} \mathrm{PCH}_{2} \mathrm{CH}=\mathrm{CH}_{2}$ (24) in good yield. The compounds were purified by extraction with n-hexane because of distillation under reduced pressure resulted in partial decomposition. The new phosphine-olefin compounds were characterized by elemental analysis, mass spectra and multinuclear NMR spectroscopy. In particular, the ${ }^{31} \mathrm{P}\left\{{ }^{1} \mathrm{H}\right\}$ NMR spectra showed high field resonances at $\delta-17.95(\mathbf{2 3})$ and -48.84 ppm (24).

$\mathrm{R}_{2} \mathrm{PX} \stackrel{\text { allylMgBr }}{\longrightarrow} \mathrm{R}_{2} \mathrm{P} \longrightarrow$

Scheme 6

In summary, we have described the synthesis of a series of functionalized phosphines of hemilabile character, $\mathrm{R}_{2} \mathrm{P}\left(\mathrm{CH}_{2}\right)_{\mathrm{n}} \mathrm{Z}\left(\mathrm{n}=2,3 ; \mathrm{Z}=\mathrm{OMe}, \mathrm{OEt}, \mathrm{O} n-\mathrm{Bu}, \mathrm{NMe}_{2}\right)$, from diarylphosphines and functionalized halogenoalkanes, $\mathrm{X}\left(\mathrm{CH}_{2}\right)_{\mathrm{n}} \mathrm{Z}$, or unsaturated compounds as vinyl or allyl ethers and allylamine derivatives. The more convenient approach for the preparation of a variety of secondary aryl phosphines, $\mathrm{R}_{2} \mathrm{PH}$, is the arylation of diethylphosphonate and posterior reduction, whereas that the more efficient methodology to introduce the hemilabile fragment is the photochemically hydrophosphination of functionalized unsaturated compounds. This reaction usually takes place under visible light with complete regioselectivity. These phosphines constitute a library of hemilabile phosphine ligands that is built by modification of the electronic density on the $\mathrm{P}$ donor atom, the donor group on the hemilabile fragment or the length of the flexible carbon chain, and that can be easily enlarged by using both synthetic proposed methods successively. 
Scientific Equipment. C, H and N analysis were carried out in a Perkin-Elmer $2400 \mathrm{CHNS} / \mathrm{O}$ analyzer. NMR spectra were recorded on a Varian Gemini 2000 or Bruker Avance 300 spectrometers, ${ }^{1} \mathrm{H}$ and ${ }^{13} \mathrm{C}$ NMR chemical shifts were referenced relative to partially deuterated solvent peaks and reported in ppm relative to tetramethylsilane. ${ }^{31} \mathrm{P}$ and ${ }^{19} \mathrm{~F}$ NMR chemical shifts were referenced relative to $\mathrm{H}_{3} \mathrm{PO}_{4}(85 \%)$ and $\mathrm{CFCl}_{3}$, respectively. Coupling constants $(J)$ are given in Hertz. MS data (EI) were recorded on a VG Autospec doublefocusing mass spectrometer operating in the positive mode; ions were produced with the $\mathrm{Cs}+$ gun at ca. 30 $\mathrm{kV}$. MALDI-TOF mass spectra were obtained on a Bruker MICROFLEX spectrometer using DCTB as matrix. ${ }^{20}$ Distillations under reduced pressure were carried out in an standard Kugelrohr oven.

\section{General Procedure for the Preparation of Diarylchlo- rophosphines $\left(\mathbf{R}_{2} \mathbf{P C l}\right)$.}

The appropriate bromoalkylbenzene $(0.06 \mathrm{~mol})$ was added to a suspension of magnesium turnings (1.54 g, $0.06 \mathrm{~mol})$ in THF or diethyl ether $(50 \mathrm{~mL})$ containing iodine $(5 \mathrm{mg})$ and the mixture stirred at room temperature or under reflux until consumption of magnesium. The suspension was filtered through celite to give clear solutions of $\mathrm{RMgCl}$. These solutions were dropwise added to a solution of $\left(\mathrm{Et}_{2} \mathrm{~N}\right) \mathrm{PCl}_{2}(5.48 \mathrm{~g}, 0.027 \mathrm{~mol})$ in diethyl ether or THF $(50 \mathrm{~mL})$ at $-5^{\circ} \mathrm{C}$ under argon. The mixture was stirred for several hours at room temperature and filtered through celite to give clear solutions of $\left(\mathrm{Et}_{2} \mathrm{~N}\right) \mathrm{PR}_{2}$. Anhydrous $\mathrm{HCl}(\mathrm{g})$ was bubbled through these solutions for $30 \mathrm{~min}$. to give a white suspension that was filtered through celite. The solutions were evaporated under vacuum to give the compounds $\mathrm{R}_{2} \mathrm{PCl}$. The compounds were purified by distillation under reduced pressure and isolated as colorless oils.

General Procedure for the Preparation of Diarylphosphine Oxides $\left(\mathbf{R}_{\mathbf{2}} \mathbf{P}(\mathbf{O}) \mathbf{H}\right)$. A freshly prepared solution of the appropriate Grignard reagent $\mathrm{RMgX}$ $(0.08 \mathrm{mmol})$, prepared in THF as described above, was dropwise added to a solution of $(\mathrm{EtO}){ }_{2} \mathrm{P}(\mathrm{O}) \mathrm{H}(2.24 \mathrm{~g}$, $0.016 \mathrm{~mol})$ in tetrahydrofurane $(75 \mathrm{~mL})$ at $5{ }^{\circ} \mathrm{C}$ and stirred for two hours. The reaction mixture was quenched by slow addition of water $(50 \mathrm{~mL})$, followed by addition of $\mathrm{HCl}(\mathrm{aq})(6 \mathrm{M}, 12 \mathrm{~mL})$ and toluene (40 $\mathrm{mL}$ ). The organic layer was removed and the aqueous layer extracted with diethyl ether $(2 \times 20 \mathrm{~mL})$. The combined organic layers were washed with $\mathrm{NaHCO}_{3}$ (ac) $(5 \%, 40 \mathrm{~mL})$ and $\mathrm{NaCl}(\mathrm{aq})(5 \%, 40 \mathrm{~mL})$, and dried over $\mathrm{MgSO}_{4}$. The solution was concentrated under reduced pressure and the residue recrystallized from hexane to give the compounds as white solids.

General Procedures for the Preparation of Diarylphosphines $\left(\mathbf{R}_{2} \mathbf{P H}\right)$. Diarylphosphines were obtained through one of the following procedures.
Preparation from $\mathrm{R}_{2} \mathrm{PCl}$ : Solid $\mathrm{LiAlH}_{4}(0.95 \mathrm{~g}, 25.03$ mmol) was added to solutions of $\mathrm{R}_{2} \mathrm{PCl}(10 \mathrm{mmol})$ in diethyl ether $(25 \mathrm{~mL})$ at $-15^{\circ} \mathrm{C}$ over a period of $30 \mathrm{~min}$. The suspensions were stirred for $1 \mathrm{~h}$ at room temperature and then treated with $\mathrm{HCl}(\mathrm{ac})(0.1 \mathrm{M}, 100 \mathrm{~mL})$. The organic layer was removed by cannula under argon and the aqueous layer extracted with diethyl ether $(2 \times 20$ $\mathrm{mL}$ ). The combined organic layers were dried over $\mathrm{MgSO}_{4}$ and the solvent evaporated under vacuum to give colorless oils that were distilled under reduced pressure

Reduction of $R_{2} P(O) H$. Solutions of the appropriate diarylphosphine oxide $(8.0 \mathrm{mmol})$ in DME $(10 \mathrm{~mL})$ were reacted with methyl iodide $(0.56 \mathrm{~mL}, 9.0 \mathrm{mmol})$ at room temperature under an argon atmosphere. After $2 \mathrm{~h}$, solid $\mathrm{LiAlH}_{4}(0.76 \mathrm{~g}, 20 \mathrm{mmol})$ and THF $(20 \mathrm{~mL})$ were added at $0{ }^{\circ} \mathrm{C}$ and the mixture stirred for $30 \mathrm{~min}$. The reaction was quenched with deoxygenated water $(10 \mathrm{~mL})$ and the organic layer removed by cannula under argon. The aqueous layer was extracted with diethyl ether $(2 \times 20$ $\mathrm{mL}$ ) and the combined organic layers dried over $\mathrm{MgSO}_{4}$. The solvent was evaporated under vacuum and the viscous oils distilled under reduced pressure.

General Procedures for the Preparation of Functionalized Phosphines $\mathrm{R}_{2} \mathrm{P}\left(\mathrm{CH}_{2}\right)_{\mathrm{n}} \mathrm{Z}(\mathrm{n}=2,3 ; \mathrm{Z}=\mathrm{OR}$, $\mathrm{NMe}_{2}$ ) and $\mathrm{R}_{2} \mathrm{PCH}_{2} \mathrm{CH}=\mathrm{CH}_{2}$.

Alkylation of LiPR (Method 1). A solution of $\mathrm{R}_{2} \mathrm{PH}$ $(8.11 \mathrm{mmol})$ in tetrahydrofuran $(50 \mathrm{~mL})$ was reacted with a solution of $n$-butyl lithium $(5.07 \mathrm{~mL}, 8.11 \mathrm{mmol}$, 1.6 $\mathrm{M}$ in hexane) under argon at $0{ }^{\circ} \mathrm{C}$ to give a solution of $\mathrm{LiPR}_{2}$. Then, the corresponding halo-alkyl methyl ether $(8.11 \mathrm{mmol})$ was added dropwise under argon at 0 ${ }^{\circ} \mathrm{C}$ and the solution allow to warm to room temperature. After stirring for 1 hour deoxygenated water $(25 \mathrm{~mL})$ was added slowly. The organic layer was removed by cannula under argon and the aqueous layer extracted with diethyl ether $(2 \times 20 \mathrm{~mL})$. The combined organic layers were dried over $\mathrm{MgSO}_{4}$, and the solvent evaporated to give viscous oils that were distilled under reduced pressure to give the compounds as colorless oils.

\section{Alkylation of $\mathbf{R}_{\mathbf{2}}\left(\mathrm{BH}_{3}\right) \mathbf{P H}$ under Phase-transfer Ca-} talysis (Method 2). $\mathrm{R}_{2} \mathrm{PH}(3.1 \mathrm{mmol})$ and $\mathrm{BH}_{3}$-THF $(3.4$ mmol) were reacted in THF $(5 \mathrm{~mL})$ at $0{ }^{\circ} \mathrm{C}$ for 3 hours to give the adducts $\mathrm{R}_{2}\left(\mathrm{BH}_{3}\right) \mathrm{PH}$. Then, the solvent was removed under vacuum and a solution of tetrabutylammonium bromide $(0.30 \mathrm{mmol})$ in $30 \% \mathrm{KOH}(\mathrm{aq})(15 \mathrm{~mL})$ and toluene $(10 \mathrm{~mL})$ were added and reacted with (2bromoethyl) methyl ether $(2.99 \mathrm{mmol})$. The mixture was stirred vigorously at room temperature for $1 \mathrm{~h}$ and the organic layer diluted with diethyl ether $(50 \mathrm{~mL})$ washed with water, brine and dried over $\mathrm{MgSO}_{4}$. The solvent was removed under reduced pressure and the residue purified by chromatography (silica gel, 2\% EtOAc/hexanes) to give the compounds $\mathrm{R}_{2}\left(\mathrm{BH}_{3}\right) \mathrm{P}\left(\mathrm{CH}_{2}-\right.$ $\left.\mathrm{CH}_{2}-\mathrm{OMe}\right)$. The phosphine-borane adducts were treated 
with $\mathrm{HBF}_{4} \cdot \mathrm{OMe}_{2}(15 \mathrm{mmol})$ in $\mathrm{CH}_{2} \mathrm{Cl}_{2}(50 \mathrm{~mL})$ at $-5^{\circ} \mathrm{C}$, and stirred for $12 \mathrm{~h}$ at room temperature followed by hydrolysis at $0{ }^{\circ} \mathrm{C}$ with an aqueous solution of $\mathrm{K}_{2} \mathrm{CO}_{3}$ (15 mmol). The organic layer was removed by cannula under argon and the aqueous layer extracted with dichloromethane $(2 \times 20 \mathrm{~mL})$. The combined organic layers were dried over $\mathrm{MgSO}_{4}$ and the solvent removed under vacuum to give the compounds as colorless oils that were distilled under reduced pressure.

Photochemical Hydrophosphination of Unsaturated compounds (Method 3). A glass reaction tube fitted with a greaseless high-vacuum stopcock was charged with the corresponding vinyl ether, allyl ether or allylamine (10 $\mathrm{mmol})$ and the appropriate diarylphosphine $(2 \mathrm{mmol})$. The mixture was placed between four white lamps of $400 \mathrm{~W}$ and stirred for $3-7$ days. The obtained viscous oil was dissolved in toluene $(10 \mathrm{~mL})$ and transferred to a Schlenck tube under argon. The volatiles were removed under vacuum to give the compounds as colorless oily products.

General Procedure for the Preparation of $\mathbf{R}_{2} \mathbf{P C H} \mathbf{H}_{2} \mathbf{C H}=\mathbf{C H}_{2}$ (Method 4). A solution of allylMgBr $(0.06 \mathrm{~mol})$ in dry diethyl ether $(100 \mathrm{~mL})$ was added dropwise under argon to a solution of $\mathrm{R}_{2} \mathrm{PCl}(0.06 \mathrm{~mol})$ in diethyl ether $(20 \mathrm{~mL})$ at $0{ }^{\circ} \mathrm{C}$. After stirring for $2 \mathrm{~h}$, the reaction mixture was hydrolyzed with a deoxygenated saturated water solution of $\mathrm{NH}_{4} \mathrm{Cl}(100 \mathrm{~mL})$. The organic layer was removed by cannula under argon and the aqueous layer extracted with diethyl ether $(2 \times 20 \mathrm{~mL})$. The combined organic layers were dried over $\mathrm{Na}_{2} \mathrm{SO}_{4}$, and the solvent removed under reduced pressure to give colorless oily that was purified by extraction from nhexane.

$\left(\mathbf{C}_{6} \mathbf{H}_{5}-\mathbf{C H}_{2}\right)_{2} \mathbf{P}\left(\mathbf{C H}_{2}\right)_{2} \mathbf{O M e}(\mathbf{8})$. bp $225{ }^{\circ} \mathrm{C}$ at 0.075 mmHg in Kugelrohr. Yield: $65 \%$ (Method 1), $89.5 \%$ (Method 2). Anal. Calcd for $\mathrm{C}_{17} \mathrm{H}_{21} \mathrm{OP}: \mathrm{C}, 74.98 ; \mathrm{H}$, 7.77. Found: C, 75.34; H, 7.99. MS (EI+, $m / z, \%): 272.8$ $\left(\mathrm{M}^{+}, 70\right) .{ }^{1} \mathrm{H}$ NMR $\left(298 \mathrm{~K}, \mathrm{CDCl}_{3}\right): \delta 7.35-7.18(\mathrm{~m}, 8 \mathrm{H}$, $\mathrm{Ph}), 3.79\left(\mathrm{~m}, 2 \mathrm{H}, \mathrm{CH}_{2} \mathrm{O}\right), 3.27\left(\mathrm{~s}, 3 \mathrm{H}, \mathrm{CH}_{3} \mathrm{O}\right), 2.86(\mathrm{~m}$, $\left.4 \mathrm{H}, \mathrm{C}_{6} \mathrm{H}_{5}-\mathrm{CH}_{2}\right), 1.69\left(\mathrm{t}, 2 \mathrm{H}, J_{\mathrm{H}-\mathrm{H}}=7.4, \mathrm{CH}_{2} \mathrm{P}\right) .{ }^{31} \mathrm{P}\left\{{ }^{1} \mathrm{H}\right\}$ NMR (298 K, CDCl $\left.]_{3}\right): \delta-21.84(\mathrm{~s}) .{ }^{13} \mathrm{C}\left\{{ }^{1} \mathrm{H}\right\}$ NMR $(298$ $\left.\mathrm{K}, \mathrm{CDCl}_{3}\right): \delta 137.72\left(\mathrm{~d}, J_{\mathrm{C}-\mathrm{P}}=4.6, \mathrm{C}_{\mathrm{i}}\right), 129.18\left(\mathrm{~d}, J_{\mathrm{C}-\mathrm{P}}=\right.$ $\left.5.7, \mathrm{C}_{\mathrm{o}}\right), 128,39\left(\mathrm{C}_{\mathrm{m}}\right), 125.81\left(\mathrm{~d}, J_{\mathrm{C}-\mathrm{P}}=2.1, \mathrm{C}_{\mathrm{p}}\right), 70.34(\mathrm{~d}$, $\left.J_{\mathrm{C}-\mathrm{P}}=21.8, \mathrm{CH}_{2} \mathrm{O}\right), 58.40\left(\mathrm{OCH}_{3}\right), 27.06\left(\mathrm{~d}, J_{\mathrm{C}-\mathrm{P}}=18.0\right.$, $\left.\mathrm{CH}_{2} \mathrm{P}\right), 34.84\left(\mathrm{~d}, J_{\mathrm{C}-\mathrm{P}}=17.3, \mathrm{C}_{6} \mathrm{H}_{4}-\mathrm{CH}_{2}\right)$.

(p- $\left.\mathrm{CH}_{3}-\mathrm{C}_{6} \mathbf{H}_{4}\right)_{2} \mathbf{P}\left(\mathrm{CH}_{2}\right)_{2} \mathbf{O M e}$ (9). bp $220{ }^{\circ} \mathrm{C}$ at 0.075 mmHg in Kugelrohr. Yield: $46 \%$ (Method 1), $83.4 \%$ (Method 2), $87.3 \%$ (Method 3). Anal. Calcd for $\mathrm{C}_{17} \mathrm{H}_{21} \mathrm{OP}$ : C, 75.02; H, 7.77. Found: C, 74.77; H, 8.22. MS (EI+, $m / z, \%): 273.4 \quad\left(\mathrm{M}^{+}, 40\right), 215.1 \quad\left(\mathrm{M}^{+}\right.$$\left.\mathrm{CH}_{2} \mathrm{CH}_{2} \mathrm{OMe}, 50\right) .{ }^{1} \mathrm{H}$ NMR $\left(298 \mathrm{~K}, \mathrm{CDCl}_{3}\right): \delta 7.36-$ $7.15(\mathrm{~m}, 8 \mathrm{H}, \mathrm{Ph}), 3.50\left(\mathrm{dt}, J_{\mathrm{H}-\mathrm{H}}=7.7 ; J_{\mathrm{H}-\mathrm{P}}=7.7,2 \mathrm{H}\right.$, $\left.\mathrm{CH}_{2} \mathrm{O}\right), 3.32\left(\mathrm{~s}, 3 \mathrm{H}, \mathrm{CH}_{3} \mathrm{O}\right), 2.39\left(\mathrm{t}, J_{\mathrm{H}-\mathrm{H}}=7.72 \mathrm{H}\right.$, $\left.\mathrm{CH}_{2} \mathrm{P}\right), 2.36\left(\mathrm{~s}, 6 \mathrm{H}, \mathrm{CH}_{3}-\mathrm{C}_{6} \mathrm{H}_{4}\right) .{ }^{31} \mathrm{P}\left\{{ }^{1} \mathrm{H}\right\}$ NMR $(298 \mathrm{~K}$, $\left.\mathrm{CDCl}_{3}\right): \delta-24.60(\mathrm{~s}) .{ }^{13} \mathrm{C}\left\{{ }^{1} \mathrm{H}\right\}$ NMR $\left(298 \mathrm{~K}, \mathrm{CDCl}_{3}\right): \delta$
$138.54\left(\mathrm{C}_{4 \mathrm{io}}\right), 134.90\left(\mathrm{~d}, J_{\mathrm{C}-\mathrm{P}}=11.8, \mathrm{C}_{\mathrm{i}}\right), 132.60\left(\mathrm{~d}, J_{\mathrm{C}-\mathrm{P}}\right.$ $\left.=19.0, \mathrm{C}_{\mathrm{o}}\right), 129.25\left(\mathrm{~m}, J_{\mathrm{C}-\mathrm{P}}=6.9, \mathrm{C}_{\mathrm{m}}\right), 69.92\left(\mathrm{~d}, J_{\mathrm{C}-\mathrm{P}}=\right.$ $\left.29.4, \mathrm{CH}_{2} \mathrm{O}\right), 58.43\left(\mathrm{OCH}_{3}\right), 28.89\left(\mathrm{~d}, J_{\mathrm{C}-\mathrm{P}}=12.5\right.$, $\left.\mathrm{CH}_{2} \mathrm{P}\right), 21.24\left(\mathrm{CH}_{3}-\mathrm{C}_{6} \mathrm{H}_{4}\right)$.

(o-C $\left.\mathbf{C H}_{3}-\mathbf{C}_{6} \mathbf{H}_{4}\right)_{2} \mathbf{P}\left(\mathbf{C H}_{2}\right)_{2} \mathbf{O M e ~ ( 1 0 ) . ~ b p ~} 200{ }^{\circ} \mathrm{C}$ at 0.075 mmHg in Kugelrohr. Yield: $41 \%$ (Method 1), $81.2 \%$ (Method 2), $89 \%$ (Method 3). Anal. Calcd for $\mathrm{C}_{17} \mathrm{H}_{21} \mathrm{OP}: \mathrm{C}, 75.02 ; \mathrm{H}, 7.77$. Found: C, 76.06; H, 8.83. MS (EI+, $m / z, \%) ; 272.7 \quad\left(\mathrm{M}^{+}, 80\right), 214.5 \quad\left(\mathrm{M}^{+}-\right.$ $\left.\mathrm{CH}_{2} \mathrm{CH}_{2} \mathrm{OMe}, 100\right) .{ }^{1} \mathrm{H}$ NMR $\left(298 \mathrm{~K}, \mathrm{CDCl}_{3}\right): \delta 7.27-$ $7.16(\mathrm{~m}, 8 \mathrm{H}, \mathrm{Ph}), 3.51\left(\mathrm{dt}, J_{\mathrm{H}-\mathrm{H}}=7.5, J_{\mathrm{H}-\mathrm{P}}=7.5,2 \mathrm{H}\right.$, $\left.\mathrm{CH}_{2} \mathrm{O}\right), 3.33$ (s, $\left.3 \mathrm{H}, \mathrm{CH}_{3} \mathrm{O}\right), 2.43$ (s, $\left.3 \mathrm{H}, \mathrm{CH}_{3}-\mathrm{C}_{6} \mathrm{H}_{4}\right)$, $2.34\left(\mathrm{t}, 2 \mathrm{H}, J_{\mathrm{H}-\mathrm{H}}=7.5, \mathrm{CH}_{2} \mathrm{P}\right) .{ }^{31} \mathrm{P}\left\{{ }^{1} \mathrm{H}\right\}$ NMR $(298 \mathrm{~K}$, $\left.\mathrm{CDCl}_{3}\right): \delta-43.97$ (s). ${ }^{13} \mathrm{C}\left\{{ }^{1} \mathrm{H}\right\}$ NMR $\left(298 \mathrm{~K}, \mathrm{CDCl}_{3}\right): \delta$ $142.34\left(\mathrm{~d}, J_{\mathrm{C}-\mathrm{P}}=25.5, \mathrm{C}_{4 \mathrm{io}}\right), 136.43\left(\mathrm{~d}, J_{\mathrm{C}-\mathrm{P}}=19.9, \mathrm{C}_{\mathrm{i}}\right)$, $131.07(\mathrm{CH}), 130.03\left(\mathrm{~d}, J_{\mathrm{C}-\mathrm{P}}=4.7, \mathrm{C}_{\mathrm{o}}\right), 128.47,126.08$ $(\mathrm{CH}), 69.80\left(\mathrm{~d}, J_{\mathrm{C}-\mathrm{P}}=24.1, \mathrm{CH}_{2} \mathrm{O}\right), 58.44\left(\mathrm{OCH}_{3}\right), 27.62$ $\left(\mathrm{d}, J_{\mathrm{C}-\mathrm{P}}=13.2, \mathrm{CH}_{2}\right), 21.15\left(\mathrm{~d}, J_{\mathrm{C}-\mathrm{P}}=21.9, \mathrm{CH}_{3}-\mathrm{C}_{6} \mathrm{H}_{4}\right)$.

$\left(\boldsymbol{p}-\mathrm{CH}_{3}-\mathbf{C}_{6} \mathbf{H}_{4}\right)_{2} \mathbf{P}\left(\mathbf{C H}_{2}\right)_{2}$ OEt (11). Yield: $79 \%$ (Method 3). Anal. Calcd for $\mathrm{C}_{18} \mathrm{H}_{23} \mathrm{OP}: \mathrm{C}, 75.50 ; \mathrm{H}, 8.10$. Found: $\mathrm{C}, 75.58 ; \mathrm{H}, 8.23$. MS (EI+, $\mathrm{m} / \mathrm{z}, \%): 287.5\left(\mathrm{M}^{+}, 17\right)$, $214.1\left(\mathrm{M}+\mathrm{CH}_{2} \mathrm{CH}_{2} \mathrm{OEt}, 85\right) .{ }^{1} \mathrm{H}$ NMR $\left(298 \mathrm{~K}, \mathrm{CDCl}_{3}\right)$ : $\delta 7.26-7.05(\mathrm{~m}, 8 \mathrm{H}, \mathrm{Ph}), 3.44\left(\mathrm{dt}, J_{\mathrm{H}-\mathrm{H}}=6.8, J_{\mathrm{H}-\mathrm{P}}=6.8\right.$, $\left.2 \mathrm{H}, \mathrm{CH}_{2} \mathrm{O}\right), 3.37\left(\mathrm{q}, J_{\mathrm{H}-\mathrm{H}}=7.0, \mathrm{CH}_{2}-\mathrm{Et}\right), 2.32(\mathrm{~m}, 2 \mathrm{H}$, $\left.\mathrm{CH}_{2} \mathrm{P}\right), 2.26\left(\mathrm{~s}, 6 \mathrm{H}, \mathrm{CH}_{3}-\mathrm{C}_{6} \mathrm{H}_{4}\right), 1.09\left(\mathrm{t}, J_{\mathrm{H}-\mathrm{H}}=7.0, \mathrm{CH}_{3}-\right.$ Et). ${ }^{31} \mathrm{P}\left\{{ }^{1} \mathrm{H}\right\}$ NMR $\left(298 \mathrm{~K}, \mathrm{CDCl}_{3}\right): \delta-24.47(\mathrm{~s})$. ${ }^{13} \mathrm{C}\left\{{ }^{1} \mathrm{H}\right\}$ NMR $\left(298 \mathrm{~K}, \mathrm{CDCl}_{3}\right): \delta 138.49\left(\mathrm{C}_{4 \mathrm{io}}\right), 134.99$ $\left(\mathrm{d}, J_{\mathrm{C}-\mathrm{P}}=10.9, \mathrm{C}_{\mathrm{i}}\right), 132.61\left(\mathrm{~d}, J_{\mathrm{C}-\mathrm{P}}=19.2, \mathrm{C}_{\mathrm{o}}\right), 129.22$ $\left(\mathrm{m}, J_{\mathrm{C}-\mathrm{P}}=6.9, \mathrm{C}_{\mathrm{m}}\right), 67.82\left(\mathrm{~d}, J_{\mathrm{C}-\mathrm{P}}=25.4, \mathrm{CH}_{2} \mathrm{O}\right), 66.05$ $\left(\mathrm{CH}_{2}-\mathrm{Et}\right), 29.03\left(\mathrm{~d}, J_{\mathrm{C}-\mathrm{P}}=12.5, \mathrm{CH}_{2} \mathrm{P}\right), 21.24\left(\mathrm{CH}_{3}-\right.$ $\left.\mathrm{C}_{6} \mathrm{H}_{4}\right), 15.16\left(\mathrm{CH}_{3}\right.$-Et).

$\mathbf{P h}_{2} \mathbf{P}\left(\mathbf{C H}_{2}\right)_{3} \mathbf{O E t}$ (12). Yield: $92 \%$ (Method 3). Anal. Calcd for $\mathrm{C}_{17} \mathrm{H}_{21} \mathrm{OP}: \mathrm{C}, 74.98$; H, 7.77. Found: C, 74.86; $\mathrm{H}$, 7.37. MS (EI+, $m / z, \%): 273.6\left(\mathrm{M}^{+}+\mathrm{H}, 50\right), 243.4$ $\left(\mathrm{M}^{+}-\mathrm{Et}, 100\right) .{ }^{1} \mathrm{H}$ NMR $\left(298 \mathrm{~K}, \mathrm{CDCl}_{3}\right): \delta$ 7.52-7.28 (m, $10 \mathrm{H}, \mathrm{Ph}), 3.47\left(\mathrm{~m}, 4 \mathrm{H}, \mathrm{CH}_{2}, \mathrm{CH}_{2}-\mathrm{Et}\right), 2.10(\mathrm{~m}, 2 \mathrm{H}$, $\left.\mathrm{CH}_{2}\right), 1.72\left(\mathrm{~m}, 2 \mathrm{H}, \mathrm{CH}_{2}\right), 1.19\left(\mathrm{t}, J_{\mathrm{H}-\mathrm{H}}=7.2, \mathrm{CH}_{3}-\mathrm{Et}\right)$. ${ }^{31} \mathrm{P}\left\{{ }^{1} \mathrm{H}\right\}$ RMN $\left(298 \mathrm{~K}, \mathrm{CDCl}_{3}\right): \delta-15.90(\mathrm{~s}) .{ }^{13} \mathrm{C}\left\{{ }^{1} \mathrm{H}\right\}$ RMN $\left(298 \mathrm{~K}, \mathrm{CDCl}_{3}\right): \delta 138.12\left(\mathrm{~d}, J_{\mathrm{C}-\mathrm{P}}=10.1, \mathrm{C}_{\mathrm{i}}\right)$, $132.74\left(\mathrm{~d}, J_{\mathrm{C}-\mathrm{P}}=18.2, \mathrm{C}_{\mathrm{o}}\right), 128.67\left(\mathrm{C}_{\mathrm{p}}\right), 128.42\left(\mathrm{~d}, J_{\mathrm{C}-\mathrm{P}}=\right.$ $\left.6.7, \mathrm{C}_{\mathrm{m}}\right), 70.94\left(\mathrm{~d}, J_{\mathrm{C}-\mathrm{P}}=13.8, \mathrm{CH}_{2} \mathrm{O}\right), 67.95\left(\mathrm{OCH}_{2}-\mathrm{Et}\right)$, $26.18\left(\mathrm{~d}, J_{\mathrm{C}-\mathrm{P}}=15.6, \mathrm{CH}_{2} \mathrm{P}\right), 24.34\left(\mathrm{~d}, J_{\mathrm{C}-\mathrm{P}}=9.5, \mathrm{CH}_{2}\right)$.

$\mathbf{P h}_{2} \mathbf{P}\left(\mathbf{C H}_{2}\right)_{3} \mathbf{O n}$-Bu (13). Yield: 64 \% (Method 3). Anal. Calcd for $\mathrm{C}_{19} \mathrm{H}_{25}$ OP. C, 75.97; H, 8.39. Found: C, 75.91; $\mathrm{H}, 8.35$. MS (MALDI-TOF, DCTB matrix, $\mathrm{CH}_{2} \mathrm{Cl}_{2}$ ) $\mathrm{m} / \mathrm{z}$ : $300.4\left(\mathrm{M}^{+}\right), 226.7\left(\mathrm{M}^{+}-\mathrm{OBu}\right) .{ }^{1} \mathrm{H}$ NMR $\left(298 \mathrm{~K}, \mathrm{CDCl}_{3}\right)$ : $\delta$ 7.46-7.31 (m, $10 \mathrm{H}, \mathrm{Ph}), 3.47\left(\mathrm{t}, 2 \mathrm{H}, J_{\mathrm{H}-\mathrm{H}}=6.4, \mathrm{CH}_{2}\right)$, $3.38\left(\mathrm{t}, J_{\mathrm{H}-\mathrm{H}}=6.6, \mathrm{CH}_{2}-\mathrm{Bu}\right), 2.10\left(\mathrm{~m}, 2 \mathrm{H}, \mathrm{CH}_{2}\right), 1.71(\mathrm{~m}$, $\left.2 \mathrm{H}, \mathrm{CH}_{2}\right), 1.55\left(\mathrm{~m}, 2 \mathrm{H}, \mathrm{CH}_{2}-\mathrm{Bu}\right), 1.36\left(\mathrm{~m}, 2 \mathrm{H}, \mathrm{CH}_{2}-\mathrm{Bu}\right)$, $0.92\left(\mathrm{t}, J_{\mathrm{H}-\mathrm{H}}=7.3, \mathrm{CH}_{3}-\mathrm{Bu}\right) .{ }^{31} \mathrm{P}\left\{{ }^{1} \mathrm{H}\right\}$ RMN $(298 \mathrm{~K}$, $\left.\mathrm{CDCl}_{3}\right): \delta-16.15(\mathrm{~s}) .{ }^{13} \mathrm{C}\left\{{ }^{1} \mathrm{H}\right\} \operatorname{RMN}\left(298 \mathrm{~K}, \mathrm{CDCl}_{3}\right): \delta$ $138.74\left(\mathrm{~d}, J_{\mathrm{C}-\mathrm{P}}=12.7, \mathrm{C}_{\mathrm{i}}\right), 132.73\left(\mathrm{~d}, J_{\mathrm{C}-\mathrm{P}}=18.4, \mathrm{C}_{\mathrm{o}}\right)$, $128.51\left(\mathrm{~m}, \mathrm{C}_{\mathrm{p}}+\mathrm{C}_{\mathrm{m}}\right), 71.23\left(\mathrm{~d}, J_{\mathrm{C}-\mathrm{P}}=13.9, \mathrm{CH}_{2} \mathrm{O}\right), 70.57$ $\left(\mathrm{OCH}_{2}-\mathrm{Bu}\right), 31.83\left(\mathrm{CH}_{2}-\mathrm{Bu}\right), 26.21\left(\mathrm{~d}, J_{\mathrm{C}-\mathrm{P}}=16.2\right.$, $\left.\mathrm{CH}_{2} \mathrm{P}\right), 24.46\left(\mathrm{~d}, J_{\mathrm{C}-\mathrm{P}}=11.2, \mathrm{CH}_{2}\right), 19.38\left(\mathrm{CH}_{2}-\mathrm{Bu}\right)$, $13.97\left(\mathrm{CH}_{3}-\mathrm{Bu}\right)$.

(p- $\left.\mathbf{C H}_{3}-\mathbf{C}_{6} \mathbf{H}_{4}\right)_{2} \mathbf{P}\left(\mathbf{C H}_{2}\right)_{3} \mathbf{O M e}$ (14) Yield: $92 \%$ (Method 3). Anal. Calcd for $\mathrm{C}_{18} \mathrm{H}_{23} \mathrm{OP}: \mathrm{C}, 75.50 ; \mathrm{H}, 8.09$. Found: C, 75.61; H, 8.15. MS (MALDI-TOF, DCTB matrix, 
$\left.\mathrm{CH}_{2} \mathrm{Cl}_{2}\right): 287.1\left(\mathrm{M}^{+}+\mathrm{H}\right), 271.1\left(\mathrm{M}^{+}-\mathrm{OMe}\right) .{ }^{1} \mathrm{H}$ NMR $\left(298 \mathrm{~K}, \mathrm{CDCl}_{3}\right): \delta 7.37-7.15(\mathrm{~m}, 8 \mathrm{H}, \mathrm{Ph}), 3.45\left(\mathrm{t}, J_{\mathrm{H}-\mathrm{H}}=\right.$ 6.8, $\left.2 \mathrm{H}, \mathrm{CH}_{2} \mathrm{O}\right), 3.32\left(\mathrm{~s}, 3 \mathrm{H}, \mathrm{CH}_{3} \mathrm{O}\right), 2.35\left(\mathrm{~s}, 6 \mathrm{H}, \mathrm{CH}_{3}-\right.$ $\left.\mathrm{C}_{6} \mathrm{H}_{4}\right), 2.08\left(\mathrm{~m}, 2 \mathrm{H}, \mathrm{CH}_{2}\right), 1.72\left(\mathrm{~m}, 2 \mathrm{H}, \mathrm{CH}_{2}\right) .{ }^{31} \mathrm{P}\left\{{ }^{1} \mathrm{H}\right\}$ NMR $\left(298 \mathrm{~K}, \mathrm{CDCl}_{3}\right): \delta-18.00(\mathrm{~s}) .{ }^{13} \mathrm{C}\left\{{ }^{1} \mathrm{H}\right\}$ NMR $\left(298 \mathrm{~K}, \mathrm{CDCl}_{3}\right): \delta 138.36\left(\mathrm{C}_{4 \mathrm{io}}\right), 135.40\left(\mathrm{~d}, J_{\mathrm{C}-\mathrm{P}}=11.9\right.$, $\left.\mathrm{C}_{\mathrm{i}}\right), 132.64\left(\mathrm{~d}, J_{\mathrm{C}-\mathrm{P}}=19.0, \mathrm{C}_{\mathrm{o}}\right), 129.18\left(\mathrm{~m}, J_{\mathrm{C}-\mathrm{P}}=7.1\right.$, $\left.\mathrm{C}_{\mathrm{m}}\right), 73.23\left(\mathrm{~d}, J_{\mathrm{C}-\mathrm{P}}=13.4, \mathrm{CH}_{2} \mathrm{O}\right), 58.43(\mathrm{OMe}), 26.12$ $\left(\mathrm{d}, J_{\mathrm{C}-\mathrm{P}}=16.6, \mathrm{CH}_{2} \mathrm{P}\right), 24.63\left(\mathrm{~d}, J_{\mathrm{C}-\mathrm{P}}=10.3, \mathrm{CH}_{2}\right), 21.23$ $\left(\mathrm{CH}_{3}-\mathrm{C}_{6} \mathrm{H}_{4}\right)$.

$\left(\boldsymbol{p}-\mathrm{CH}_{3}-\mathbf{C}_{6} \mathbf{H}_{4}\right)_{2} \mathbf{P}\left(\mathbf{C H}_{2}\right)_{3} \mathbf{O E t}$ (15). Yield: $65 \%$ (Method 3). Anal. Calcd for $\mathrm{C}_{19} \mathrm{H}_{25} \mathrm{OP}: \mathrm{C}, 76.02 ; \mathrm{H}, 8.33$. Found: C, 75.86; H, 8.37. MS (EI+, $m / z, \%): 301\left(\mathrm{M}^{+}, 30\right), 271$ $\left(\mathrm{M}^{+}-\mathrm{Et}, 85\right), 227\left(\mathrm{M}+\mathrm{CH}_{2} \mathrm{CH}_{2} \mathrm{OEt}, 100\right) .{ }^{1} \mathrm{H}$ NMR $(298$ $\left.\mathrm{K}, \mathrm{CDCl}_{3}\right): \delta 7.23-7.02(\mathrm{~m}, 8 \mathrm{H}, \mathrm{Ph}), 3.45\left(\mathrm{~m}, 4 \mathrm{H}, \mathrm{CH}_{2} \mathrm{O}\right.$, $\left.\mathrm{CH}_{2}-\mathrm{Et}\right), 2.23\left(\mathrm{~s}, \mathrm{CH}_{3}-\mathrm{C}_{6} \mathrm{H}_{4}\right), 1.96\left(\mathrm{~m}, 2 \mathrm{H}, \mathrm{CH}_{2}\right), 1.59$ $\left(\mathrm{m}, 2 \mathrm{H}, \mathrm{CH}_{2}\right), 1.08\left(\mathrm{t}, J_{\mathrm{H}-\mathrm{H}}=7.0, \mathrm{CH}_{3}-\mathrm{Et}\right) .{ }^{31} \mathrm{P}\left\{{ }^{1} \mathrm{H}\right\} \mathrm{NMR}$ $\left(298 \mathrm{~K}, \mathrm{CDCl}_{3}\right): \delta-18.14(\mathrm{~s}) .{ }^{13} \mathrm{C}\left\{{ }^{1} \mathrm{H}\right\}$ NMR $(298 \mathrm{~K}$, $\left.\mathrm{CDCl}_{3}\right): \delta 138.36\left(\mathrm{C}_{4 \mathrm{io}}\right), 135.36\left(\mathrm{~d}, J_{\mathrm{C}-\mathrm{P}}=11.4, \mathrm{C}_{\mathrm{i}}\right)$, $132.65\left(\mathrm{~d}, J_{\mathrm{C}-\mathrm{P}}=18.5, \mathrm{C}_{\mathrm{o}}\right), 129.17\left(\mathrm{~m}, J_{\mathrm{C}-\mathrm{P}}=6.9, \mathrm{C}_{\mathrm{m}}\right)$, $71.12\left(\mathrm{~d}, J_{\mathrm{C}-\mathrm{P}}=13.9, \mathrm{CH}_{2} \mathrm{O}\right), 66.01\left(\mathrm{CH}_{2}-\mathrm{Et}\right), 26.24(\mathrm{~d}$, $\left.J_{\mathrm{C}-\mathrm{P}}=16.5, \mathrm{CH}_{2} \mathrm{P}\right), 24.65\left(\mathrm{~d}, J_{\mathrm{C}-\mathrm{P}}=11.2, \mathrm{CH}_{2}\right), 21.27$ $\left(\mathrm{CH}_{3}-\mathrm{C}_{6} \mathrm{H}_{4}\right), 15.22\left(\mathrm{CH}_{3}-\mathrm{Et}\right)$.

$\left(p-\mathrm{CH}_{3}-\mathbf{C}_{6} \mathbf{H}_{4}\right)_{2} \mathbf{P}\left(\mathrm{CH}_{2}\right)_{3} \mathrm{NMe}_{2}$ (16). Yield: $55 \%$ (Method 3). Anal. Calcd for $\mathrm{C}_{19} \mathrm{H}_{26} \mathrm{NP}: \mathrm{C}, 76.22 ; \mathrm{H}, 8.75 ; \mathrm{N}$, 4.68. Found: C, 76.28; H, 8.77; N, 4.61. MS (EI+, $m / z$, \%): $299.3\left(\mathrm{M}^{+}, 30\right), 241.2\left(\mathrm{M}^{+}-\mathrm{CH}_{2} \mathrm{NMe}_{2}, 100\right), 227.2$ $\left(\mathrm{M}+\mathrm{CH}_{2} \mathrm{CH}_{2} \mathrm{NMe}_{2}, 100\right) .{ }^{\mathrm{l}} \mathrm{H}$ NMR $\left(298 \mathrm{~K}, \mathrm{CDCl}_{3}\right): \delta$ 7.34-7.12 (m, 8H, Ph), $2.38\left(\mathrm{~m}, 2 \mathrm{H}, \mathrm{CH}_{2}\right), 2.33(\mathrm{~s}, 6 \mathrm{H}$, $\left.\mathrm{CH}_{3}-\mathrm{C}_{6} \mathrm{H}_{4}\right), 2.17\left(\mathrm{~s}, 6 \mathrm{H}, \mathrm{NMe}_{2}\right), 2.03\left(\mathrm{~m}, 2 \mathrm{H}, \mathrm{CH}_{2}\right), 1.57$ $\left(\mathrm{m}, 2 \mathrm{H}, \mathrm{CH}_{2}\right) \cdot{ }^{31} \mathrm{P}\left\{{ }^{1} \mathrm{H}\right\}$ NMR $\left(298 \mathrm{~K}, \mathrm{CDCl}_{3}\right): \delta-17.98$ (s). ${ }^{13} \mathrm{C}\left\{{ }^{1} \mathrm{H}\right\}$ NMR $\left(298 \mathrm{~K}, \mathrm{CDCl}_{3}\right): \delta 138.69\left(\mathrm{C}_{4 \mathrm{io}}\right)$, $135.76\left(\mathrm{~d}, J_{\mathrm{C}-\mathrm{P}}=11.5, \mathrm{C}_{\mathrm{i}}\right), 132.99\left(\mathrm{~d}, J_{\mathrm{C}-\mathrm{P}}=18.4, \mathrm{C}_{\mathrm{o}}\right)$, $129.49\left(\mathrm{~m}, J_{\mathrm{C}-\mathrm{P}}=6.4, \mathrm{C}_{\mathrm{m}}\right), 61.04\left(\mathrm{~d}, J_{\mathrm{C}-\mathrm{P}}=13.8, \mathrm{CH}_{2} \mathrm{~N}\right)$, $45.61\left(\mathrm{CH}_{3}, \mathrm{NMe}_{2}\right), 26.00\left(\mathrm{~d}, J_{\mathrm{C}-\mathrm{P}}=11.1, \mathrm{CH}_{2} \mathrm{P}\right), 24.29$ $\left(\mathrm{d}, J_{\mathrm{C}-\mathrm{P}}=16.6, \mathrm{CH}_{2}\right), 21.19\left(\mathrm{CH}_{3}-\mathrm{C}_{6} \mathrm{H}_{4}\right)$.

$\left(\boldsymbol{p}-\mathrm{CH}_{3} \mathbf{O}-\mathrm{C}_{6} \mathbf{H}_{4}\right)_{2} \mathbf{P}\left(\mathrm{CH}_{2}\right)_{3} \mathrm{OMe}(\mathbf{1 7})$. Yield: $75 \%$ (Method 3). Anal. Calcd for $\mathrm{C}_{18} \mathrm{H}_{23} \mathrm{O}_{3}$ P. C, 67.91; H, 7.28. Found: 67.98; H, 7.31. MS (MALDI-TOF, DCTB matrix, $\left.\mathrm{CH}_{2} \mathrm{Cl}_{2}\right): 318.7\left(\mathrm{M}^{+}\right) .{ }^{1} \mathrm{H}$ NMR $\left(298 \mathrm{~K}, \mathrm{CDCl}_{3}\right): \delta$ 7.38-7.01 (m, 8H, Ph), $3.70\left(\mathrm{~s}, 6 \mathrm{H}, \mathrm{CH}_{3} \mathrm{O}\right), 3.45\left(\mathrm{q}, J_{\mathrm{H}-\mathrm{H}}\right.$ $\left.=6.8, \mathrm{~m}, 4 \mathrm{H}, \mathrm{CH}_{2} \mathrm{O}\right), 3.31\left(\mathrm{~s}, 3 \mathrm{H}, \mathrm{CH}_{3} \mathrm{O}\right), 2.05(\mathrm{~m}, 2 \mathrm{H}$, $\left.\mathrm{CH}_{2}\right), 1.71\left(\mathrm{~m}, 2 \mathrm{H}, \mathrm{CH}_{2}\right) .{ }^{31} \mathrm{P}\left\{{ }^{1} \mathrm{H}\right\}$ RMN $(298 \mathrm{~K}$, $\left.\mathrm{CDCl}_{3}\right): \delta-19.69(\mathrm{~s}) .{ }^{13} \mathrm{C}\left\{{ }^{1} \mathrm{H}\right\} \mathrm{RMN}\left(298 \mathrm{~K}, \mathrm{CDCl}_{3}\right): \delta$ $160.03\left(\mathrm{C}_{4 \mathrm{io}}\right), 133.68\left(\mathrm{~d}, J_{\mathrm{C}-\mathrm{P}}=19.3, \mathrm{C}_{\mathrm{o}}\right), 129.76\left(\mathrm{~d}, J_{\mathrm{C}-\mathrm{P}}\right.$ $\left.=10.8, \mathrm{C}_{\mathrm{i}}\right), 113.95\left(\mathrm{~d}, J_{\mathrm{C}-\mathrm{P}}=7.1, \mathrm{C}_{\mathrm{m}}\right), 72.91\left(\mathrm{~d}, J_{\mathrm{C}-\mathrm{P}}=\right.$ 13.6, $\left.\mathrm{CH}_{2} \mathrm{O}\right), 58.40(\mathrm{OMe}), 54.89\left(\mathrm{CH}_{3} \mathrm{O}\right), 26.10\left(\mathrm{~d}, J_{\mathrm{C}-\mathrm{P}}\right.$ $\left.=16.6, \mathrm{CH}_{2} \mathrm{P}\right), 24.74\left(\mathrm{~d}, J_{\mathrm{C}-\mathrm{P}}=10.4, \mathrm{CH}_{2}\right)$.

$\left(p-\mathrm{CH}_{3} \mathrm{O}-\mathrm{C}_{6} \mathrm{H}_{4}\right)_{2} \mathbf{P}\left(\mathrm{CH}_{2}\right)_{3} \mathrm{OEt}$ (18). Yield: $55 \%$ (Method 3). Anal. Calcd for $\mathrm{C}_{19} \mathrm{H}_{25} \mathrm{O}_{3}$ P. C, 68.66; H, 7.58. Found: C, 68.76; H, 7.65. MS (MALDI-TOF, DCTB matrix, $\left.\mathrm{CH}_{2} \mathrm{Cl}_{2}\right): 332.9\left(\mathrm{M}^{+}\right) .{ }^{1} \mathrm{H}$ NMR $\left(298 \mathrm{~K}, \mathrm{CDCl}_{3}\right)$ : $\delta$ 7.36-6.86 (m, 8H, Ph), $3.78\left(\mathrm{~m}, 8 \mathrm{H}, \mathrm{CH}_{3} \mathrm{O}, \mathrm{OCH}_{2}\right)$, $3.45\left(\mathrm{q}, J_{\mathrm{H}-\mathrm{H}}=6.5, \mathrm{~m}, 4 \mathrm{H}, \mathrm{CH}_{2} \mathrm{O}\right), 2.03\left(\mathrm{~m}, 2 \mathrm{H}, \mathrm{CH}_{2}\right)$, $1.68\left(\mathrm{~m}, 2 \mathrm{H}, \mathrm{CH}_{2}\right), 1.18\left(\mathrm{t}, J_{\mathrm{H}-\mathrm{H}}=6.8, \mathrm{CH}_{3}-\mathrm{Et}\right) .{ }^{31} \mathrm{P}\left\{{ }^{1} \mathrm{H}\right\}$ $\operatorname{RMN}\left(298 \mathrm{~K}, \mathrm{CDCl}_{3}\right): \delta-19.89(\mathrm{~s}) .{ }^{13} \mathrm{C}\left\{{ }^{1} \mathrm{H}\right\} \operatorname{RMN}(298$ $\left.\mathrm{K}, \mathrm{CDCl}_{3}\right): \delta 160.00\left(\mathrm{C}_{4 \mathrm{io}}\right), 133.93\left(\mathrm{~d}, J_{\mathrm{C}-\mathrm{P}}=19.8, \mathrm{C}_{\mathrm{o}}\right)$, $129.76\left(\mathrm{~d}, J_{\mathrm{C}-\mathrm{P}}=10.3, \mathrm{C}_{\mathrm{i}}\right), 113.94\left(\mathrm{~d}, J_{\mathrm{C}-\mathrm{P}}=7.4, \mathrm{C}_{\mathrm{m}}\right)$, $70.90\left(\mathrm{~d}, J_{\mathrm{C}-\mathrm{P}}=14.0, \mathrm{CH}_{2} \mathrm{O}\right), 65.78\left(\mathrm{CH}_{2}-\mathrm{Et}\right), 54.89$
$\left(\mathrm{CH}_{3} \mathrm{O}\right), 25.97\left(\mathrm{~d}, J_{\mathrm{C}-\mathrm{P}}=16.4, \mathrm{CH}_{2} \mathrm{P}\right), 24.76\left(\mathrm{~d}, J_{\mathrm{C}-\mathrm{P}}=\right.$ $\left.10.4, \mathrm{CH}_{2}\right), 14.90\left(\mathrm{CH}_{3} \mathrm{Et}\right)$.

$\left(p-\mathbf{C H}_{3} \mathbf{O}-\mathbf{C}_{6} \mathbf{H}_{4}\right)_{2} \mathbf{P}\left(\mathbf{C H}_{2}\right)_{3} \mathbf{N M e}_{2}$ (19). Yield: $75.5 \%$ (Method 3). Anal. Calcd for $\mathrm{C}_{19} \mathrm{H}_{26} \mathrm{NO}_{2} \mathrm{P}$. C, 68.86; $\mathrm{H}$, 7.91; N, 4.22. Found: C, 68.91; H, 7.77; N, 4.23. MS (MALDI-TOF, DCTB matrix, $\left.\mathrm{CH}_{2} \mathrm{Cl}_{2}\right) \mathrm{m} / \mathrm{z}: 330.2\left(\mathrm{M}^{+}\right.$). ${ }^{1} \mathrm{H}$ NMR $\left(298 \mathrm{~K}, \mathrm{CDCl}_{3}\right): \delta 7.38-6.86(\mathrm{~m}, 8 \mathrm{H}, \mathrm{Ph}), 3.80$ $\left(\mathrm{s}, 6 \mathrm{H}, \mathrm{CH}_{3} \mathrm{O}\right), 2.37\left(\mathrm{~m}, 2 \mathrm{H}, \mathrm{CH}_{2}\right), 2.20\left(\mathrm{~s}, 6 \mathrm{H}, \mathrm{NMe}_{2}\right)$, $1.98\left(\mathrm{~m}, 2 \mathrm{H}, \mathrm{CH}_{2}\right), 1.58\left(\mathrm{~m}, 2 \mathrm{H}, \mathrm{CH}_{2}\right) .{ }^{31} \mathrm{P}\left\{{ }^{1} \mathrm{H}\right\} \mathrm{RMN}$ $\left(298 \mathrm{~K}, \mathrm{CDCl}_{3}\right): \delta-19.46(\mathrm{~s}) .{ }^{13} \mathrm{C}\left\{{ }^{1} \mathrm{H}\right\}$ RMN $(298 \mathrm{~K}$, $\left.\mathrm{CDCl}_{3}\right): \delta 160.05\left(\mathrm{C}_{4 \mathrm{io}}\right), 134.03\left(\mathrm{~d}, J_{\mathrm{C}-\mathrm{P}}=19.8, \mathrm{C}_{\mathrm{o}}\right)$, $129.91\left(\mathrm{~d}, J_{\mathrm{C}-\mathrm{P}}=10.4, \mathrm{C}_{\mathrm{i}}\right) 114.10\left(\mathrm{~d}, J_{\mathrm{C}-\mathrm{P}}=7.2, \mathrm{C}_{\mathrm{m}}\right)$, $60.72\left(\mathrm{~d}, J_{\mathrm{C}-\mathrm{P}}=13.5, \mathrm{CH}_{2} \mathrm{~N}\right), 55.11\left(\mathrm{CH}_{3} \mathrm{O}\right), 45.31$ $\left(\mathrm{NMe}_{2}\right), 26.32\left(\mathrm{~d}, J_{\mathrm{C}-\mathrm{P}}=10.3, \mathrm{CH}_{2}\right), 24.02\left(\mathrm{~d}, J_{\mathrm{C}-\mathrm{P}}=\right.$ $17.2, \mathrm{CH}_{2}$ ).

$\left(\boldsymbol{p}-\mathrm{CF}_{3}-\mathrm{C}_{6} \mathbf{H}_{4}\right)_{2} \mathbf{P}\left(\mathrm{CH}_{2}\right)_{2} \mathbf{O E t}(\mathbf{2 0})$. Yield: $55.0 \%$ (Method 3). Anal. Calcd for $\mathrm{C}_{18} \mathrm{H}_{17} \mathrm{~F}_{6} \mathrm{OP}: \mathrm{C}, 54.83 ; \mathrm{H}, 4.34$. Found: C, 54.79; H, 4.28. MS (EI+, $m / z, \%): 395.7\left(\mathrm{M}^{+}+\right.$ $\mathrm{H}, 65), 322.5\left(\mathrm{M}+\mathrm{CH}_{2} \mathrm{CH}_{2} \mathrm{OEt}+\mathrm{H}, 100\right) .{ }^{1} \mathrm{H}$ NMR $\left(298 \mathrm{~K}_{1} \mathrm{CDCl}_{3}\right): \delta 7.61-7.51(\mathrm{~m}, 8 \mathrm{H}, \mathrm{Ph}), 3.58\left(\mathrm{q}, J_{\mathrm{H}-\mathrm{H}}=\right.$ $\left.7.5,2 \mathrm{H}, \mathrm{CH}_{2}-\mathrm{Et}\right), 3.46$ (q, $\left.\mathrm{J}_{\mathrm{H}-\mathrm{H}}=7.2,2 \mathrm{H}, \mathrm{CH}_{2} \mathrm{O}\right), 2.43$ (t, $\left.2 \mathrm{H}, J_{\mathrm{H}-\mathrm{H}}=7.3, \mathrm{CH}_{2}\right), 1.15\left(\mathrm{t}, J_{\mathrm{H}-\mathrm{H}}=7.1,3 \mathrm{H}, \mathrm{CH}_{3}-\mathrm{Et}\right)$. ${ }^{31} \mathrm{P}\left\{{ }^{1} \mathrm{H}\right\}$ NMR $\left(298 \mathrm{~K}, \mathrm{CDCl}_{3}\right): \delta-20.19(\mathrm{~s}) .{ }^{19} \mathrm{~F}$ NMR $\left(298 \mathrm{~K}, \mathrm{CDCl}_{3}\right): \delta-65.11(\mathrm{~s}) .{ }^{13} \mathrm{C}\left\{{ }^{1} \mathrm{H}\right\}$ NMR $(298 \mathrm{~K}$, $\left.\mathrm{CDCl}_{3}\right): \delta 143.21\left(\mathrm{~d}, J_{\mathrm{C}-\mathrm{P}}=15.7, \mathrm{C}_{\mathrm{i}}-\mathrm{P}\right), 133.46,133.20$ $\left(\mathrm{C}_{\mathrm{o}}, \mathrm{C}_{\mathrm{P}}\right), 131.29\left(\mathrm{q}, J_{\mathrm{CF}}=32.6, \mathrm{C}_{4 \mathrm{io}}-\mathrm{CF}_{3}\right), 125.58(\mathrm{~m}$, $\left.\mathrm{C}_{\mathrm{m}}\right), 124.26\left(\mathrm{~d}, J_{\mathrm{CF}}=271.1, \mathrm{CF}_{3}\right), 70.61\left(\mathrm{~d}, J_{\mathrm{C}-\mathrm{P}}=12.8\right.$, $\left.\mathrm{P}-\mathrm{CH}_{2}\right), 67.41\left(\mathrm{~d}, J_{\mathrm{C}-\mathrm{P}}=22.1, \mathrm{P}-\mathrm{CH}_{2}\right), 66.54\left(\mathrm{CH}_{2}-\mathrm{Et}\right)$, $28.83\left(\mathrm{~d}, J_{\mathrm{C}-\mathrm{P}}=14.7, \mathrm{CH}_{2}\right), 15.14\left(\mathrm{CH}_{3}\right.$-Et).

$\left(\boldsymbol{p}-\mathrm{CF}_{3}-\mathrm{C}_{6} \mathbf{H}_{4}\right)_{2} \mathbf{P}\left(\mathrm{CH}_{2}\right)_{3} \mathbf{O E t}$ (21). Yield: $75 \%$ (Method 3). Anal. Calcd for $\mathrm{C}_{19} \mathrm{~F}_{6} \mathrm{H}_{19} \mathrm{OP}: \mathrm{C}, 55.89 ; \mathrm{H}, 4.69$. Found: 55.83; H, 4.68. MS (EI+, $m / z, \%): 409.7\left(\mathrm{M}^{+}+\mathrm{H}\right.$, 90), $379.3\left(\mathrm{M}-\mathrm{CH}_{2} \mathrm{CH}_{3}, 85\right) .{ }^{1} \mathrm{H}$ NMR $\left(298 \mathrm{~K}, \mathrm{CDCl}_{3}\right)$ : $\delta$ 7.62-7.53 (m, 8H, Ph), $3.46\left(\mathrm{~m}, 4 \mathrm{H}, \mathrm{CH}_{2}\right), 2.18(\mathrm{~m}$, $\left.2 \mathrm{H}, \mathrm{CH}_{2}\right), 1.71\left(\mathrm{~m}, 2 \mathrm{H}, \mathrm{CH}_{2}\right), 1.21\left(\mathrm{t}, J_{\mathrm{H}-\mathrm{H}}=7.2,3 \mathrm{H}\right.$, $\left.\mathrm{CH}_{3}-\mathrm{Et}\right) .{ }^{31} \mathrm{P}\left\{{ }^{1} \mathrm{H}\right\}$ NMR $\left(298 \mathrm{~K}, \mathrm{CDCl}_{3}\right): \delta-15.35(\mathrm{~s})$. ${ }^{19} \mathrm{~F}$ NMR $\left(298 \mathrm{~K}, \mathrm{CDCl}_{3}\right): \delta-65.11(\mathrm{~s}) .{ }^{13} \mathrm{C}\left\{{ }^{1} \mathrm{H}\right\}$ NMR $\left(298 \mathrm{~K}, \mathrm{CDCl}_{3}\right): \delta 143.07\left(\mathrm{~d}, J_{\mathrm{C}-\mathrm{P}}=16.6, \mathrm{C}_{\mathrm{i}} \mathrm{P}\right)$, ), $133.12,132.88\left(\mathrm{C}_{\mathrm{o}}, \mathrm{C}_{\mathrm{p}}\right), 132.42\left(\mathrm{~d}, J_{\mathrm{CF}}=35.9, \mathrm{C}_{4 \mathrm{i}}-\mathrm{CF}_{3}\right)$, $125.27\left(\mathrm{~m}, \mathrm{C}_{\mathrm{m}}\right), 124.09\left(\mathrm{~d}, J_{\mathrm{C}-\mathrm{P}}=285.7, \mathrm{CF}_{3}\right), 70.62(\mathrm{~d}$, $\left.J_{\mathrm{C}-\mathrm{P}}=12.8, \mathrm{CH}_{2}\right), 66.20\left(\mathrm{CH}_{2}-\mathrm{Et}\right), 26.12\left(\mathrm{~d}, J_{\mathrm{C}-\mathrm{P}}=16.6\right.$, $\left.\mathrm{CH}_{2}\right), 24.23\left(\mathrm{~d}, J_{\mathrm{C}-\mathrm{P}}=11.8, \mathrm{CH}_{2}\right), 15.15\left(\mathrm{CH}_{3}-\mathrm{Et}\right)$.

$\left(\boldsymbol{p}-\mathrm{CF}_{3}-\mathbf{C}_{6} \mathbf{H}_{4}\right)_{2} \mathbf{P}\left(\mathbf{C H}_{2}\right)_{3} \mathbf{N M e}_{2} \quad$ (22). Yield: $78.6 \%$ (Method 3). Anal. Calcd for $\mathrm{C}_{19} \mathrm{~F}_{6} \mathrm{H}_{20} \mathrm{NP}$ : C, 56.02; $\mathrm{H}$, 4.95; N, 3.44 Found: C, 56.21; 4.88; N, 3.14. MS (MALDI-TOF, DCTB matrix, $\left.\mathrm{CH}_{3} \mathrm{OH}\right) \mathrm{m} / \mathrm{z}: 408.1\left(\mathrm{M}^{+}\right.$ $+\mathrm{H}) .{ }^{1} \mathrm{H}$ NMR $\left(298 \mathrm{~K}, \mathrm{CDCl}_{3}\right): \delta$ 7.76-7.49 (m, 8H, Ph), 2.43(m, $\left.2 \mathrm{H}, \mathrm{CH}_{2}\right), 2.22\left(\mathrm{~s}, 6 \mathrm{H}, \mathrm{NMe}_{2}\right), 2.10(\mathrm{~m}, 2 \mathrm{H}$, $\left.\mathrm{CH}_{2}\right), 1.60\left(\mathrm{~m}, 2 \mathrm{H}, \mathrm{CH}_{2}\right) .{ }^{31} \mathrm{P}\left\{{ }^{1} \mathrm{H}\right\}$ NMR $(298 \mathrm{~K}$, $\left.\mathrm{CDCl}_{3}\right): \delta-15.18(\mathrm{~s}) .{ }^{19} \mathrm{~F}$ NMR $\left(298 \mathrm{~K}, \mathrm{CDCl}_{3}\right): \delta-$ $65.08(\mathrm{~s}) .{ }^{13} \mathrm{C}\left\{{ }^{1} \mathrm{H}\right\}$ NMR $\left(298 \mathrm{~K}, \mathrm{CDCl}_{3}\right): \delta 142.99(\mathrm{~d}$, $\left.J_{\mathrm{C}-\mathrm{P}}=16.4, \mathrm{C}_{\mathrm{i}}-\mathrm{P}\right), 133.09,132.85\left(\mathrm{C}_{\mathrm{o}}, \mathrm{C}_{\mathrm{p}}\right), 132.26\left(\mathrm{~d}, J_{\mathrm{CF}}\right.$ $\left.=35.4, \mathrm{C}_{4 \mathrm{io}}-\mathrm{CF}_{3}\right), 125.24\left(\mathrm{~m}, \mathrm{C}_{\mathrm{m}}\right), 124.01\left(\mathrm{~d}, J_{\mathrm{C}-\mathrm{P}}=\right.$ $\left.286.1, \mathrm{CF}_{3}\right), 60.20\left(\mathrm{~d}, J_{\mathrm{C}-\mathrm{P}}=13.6, \mathrm{CH}_{2} \mathrm{~N}\right), 45.07\left(\mathrm{CH}_{3}\right.$, $\left.\mathrm{NMe}_{2}\right), 25.26\left(\mathrm{~d}, J_{\mathrm{C}-\mathrm{P}}=12.2, \mathrm{CH}_{2}\right), 23.70\left(\mathrm{~d}, J_{\mathrm{C}-\mathrm{P}}=16.3\right.$, $\mathrm{CH}_{2}$ ).

$\left(p-\mathbf{F}-\mathrm{C}_{6} \mathrm{H}_{4}\right)_{2} \mathbf{P C H}_{2} \mathbf{C H}=\mathbf{C H}_{2}$ (23). Purification by extraction from $n$-hexane. Yield: $75 \%$ (Method 4). Anal. Calcd for $\mathrm{C}_{15} \mathrm{H}_{13} \mathrm{~F}_{2} \mathrm{P}: \mathrm{C}, 68.70 ; \mathrm{H}, 5.00$. Found: 69.02; H, 
5.30 MS (EI+, $m / z, \%): 262.4\left(\mathrm{M}^{+}, 80\right), 221.3\left(\mathrm{M}^{+}-\right.$ $\left.\mathrm{CH}_{2} \mathrm{CH}=\mathrm{CH}_{2}, 100\right) .{ }^{1} \mathrm{H}$ NMR $\left(298 \mathrm{~K}, \mathrm{CDCl}_{3}\right): \delta 7.62-$ $7.17(\mathrm{~m}, 8 \mathrm{H}, \mathrm{Ph}), 5.78(\mathrm{~m}, 1 \mathrm{H}, \mathrm{CH}=), 5.12(\mathrm{~m}, 2 \mathrm{H}$, $\left.=\mathrm{CH}_{2}\right), 2.84\left(\mathrm{~d}, J_{\mathrm{H}-\mathrm{H}}=7.2,2 \mathrm{H}, \mathrm{CH}_{2}\right) \cdot{ }^{31} \mathrm{P}\left\{{ }^{1} \mathrm{H}\right\} \mathrm{NMR}(298$ $\left.\mathrm{K}, \mathrm{CDCl}_{3}\right): \delta-17.95(\mathrm{~s}) .{ }^{19} \mathrm{~F}$ NMR $\left(298 \mathrm{~K}, \mathrm{CDCl}_{3}\right): \delta-$ $114.86(\mathrm{~s}) .{ }^{13} \mathrm{C}\left\{{ }^{1} \mathrm{H}\right\}$ NMR $\left(298 \mathrm{~K}, \mathrm{CDCl}_{3}\right): 164.81(\mathrm{~d}$, $\left.J_{\mathrm{CF}}=248.9, \mathrm{C}_{4 \mathrm{io}}-\mathrm{F}\right), 134.78-132.50(\mathrm{~m}, \mathrm{CH}),, 117.75(\mathrm{~d}$, $\left.J_{\mathrm{C}-\mathrm{P}}=10.6,=\mathrm{CH}_{2}\right), 115.76\left(\mathrm{dd}, J_{\mathrm{CF}}=20.9, J_{\mathrm{C}-\mathrm{P}}=7.2\right.$, $=\mathrm{CH}), 34.08\left(\mathrm{~d}, J_{\mathrm{C}-\mathrm{P}}=13.4, \mathrm{CH}_{2}\right)$.

$\left(\mathrm{C}_{6} \mathbf{F}_{5}\right)_{2} \mathbf{P C H} \mathrm{CH}_{2} \mathrm{CH}=\mathrm{CH}_{2}$ (24). Purification by extraction from $n$-hexane. Yield: $52 \%$ (Method 4). Anal. Calcd for $\mathrm{C}_{15} \mathrm{H}_{5} \mathrm{~F}_{10} \mathrm{P}: \mathrm{C}, 44.35 ; \mathrm{H}, 1.23$. Found: $\mathrm{C}, 44.43 ; \mathrm{H}, 2.06$. MS (EI+, $m / z, \%): 406.3(\mathrm{M}+100) .{ }^{1} \mathrm{H}$ NMR $(298 \mathrm{~K}$, $\left.\mathrm{CDCl}_{3}\right): \delta 5.75(\mathrm{~m}, 1 \mathrm{H}, \mathrm{CH}=), 5.07\left(\mathrm{~m}, 2 \mathrm{H},=\mathrm{CH}_{2}\right), 3.33$ $\left(\mathrm{d}, J_{\mathrm{H}-\mathrm{H}}=7.2,2 \mathrm{H}, \mathrm{CH}_{2}\right) \cdot{ }^{31} \mathrm{P}\left\{{ }^{1} \mathrm{H}\right\} \mathrm{NMR}\left(298 \mathrm{~K}, \mathrm{CDCl}_{3}\right)$ : $\delta-48.84\left(\mathrm{q}, J_{\mathrm{PF}}=23.4\right) .{ }^{19} \mathrm{~F}$ NMR $\left(298 \mathrm{~K}, \mathrm{CDCl}_{3}\right): \delta-$ $132.44\left(\mathrm{~m}, \mathrm{~F}_{\mathrm{o}}\right),-152.44\left(\mathrm{~m}, \mathrm{~F}_{\mathrm{m}}\right),-162.95\left(\mathrm{~m}, \mathrm{~F}_{\mathrm{p}}\right)$. ${ }^{13} \mathrm{C}\left\{{ }^{1} \mathrm{H}\right\}$ NMR $\left(298 \mathrm{~K}, \mathrm{CDCl}_{3}\right): \delta 147.80\left(\mathrm{~d}, J_{\mathrm{CF}}=247.4\right.$, $\left.\mathrm{C}_{\mathrm{o}}\right), 142.45\left(\mathrm{~d}, J_{\mathrm{CF}}=271.3, \mathrm{C}_{\mathrm{P}}\right), 137.62\left(\mathrm{~d}, J_{\mathrm{CF}}=251.5\right.$, $\left.\mathrm{C}_{\mathrm{m}}\right), 130.51\left(\mathrm{~d}, J_{\mathrm{C}-\mathrm{P}}=10.6, \mathrm{CH}=\right), 120.06\left(\mathrm{~d}, J_{\mathrm{C}-\mathrm{P}}=\right.$ $\left.12.90,=\mathrm{CH}_{2}\right), 108.58\left(\mathrm{~m}, \mathrm{C}_{\mathrm{i}}\right), 28.81\left(\mathrm{~m}, \mathrm{CH}_{2}\right)$.

\section{Acknowledgment}

The financial support from Ministerio de Educación y Ciencia (MEC/FEDER) is gratefully acknowledged (Project CTQ200603973/BQU). MIB (project BQU2003-05412-C02-01) thanks a graduate scholarship for financial support.

\section{References}

(1) Jeffrey, J. C.; Rauchfuss, T. B. Inorg. Chem. 1979, 18, $2658-2666$.

(2) (a) Braunstein, P.; Naud, F. Angew. Chem. Int. Ed. 2001, 40, 680 - 699. (b) Slone, C. S.; Weinberger, D. A.; Mirkin, C. A. Prog. Inorg. Chem. 1999, 48, $233-350$.

(3) (a) Chen, G.; Lam, W. H.; Fok, W. S.; Lee, H. W.; Kwong, F. Y. Chem. Asian J. 2007, 2, 306 - 313. (b) Chikkali, S.; Gudat, D.; Niemeyer, M. Chem. Commun. 2007, 981 983. (c) Grotjahn, D. B.; Gong, Y.; Zakharov, L.; Golen, J. A.; Rheingold, A. L. J. Am. Chem. Soc. 2006, 128, $438-$ 453. (d) Moxham, G. L.; Randell-Sly, H. E.; Brayshaw, S. K.; Woodward, R. L.; Weller, A. S.; Willis M. C. Angew. Chem. Int. Ed. 2006, 45, 7618 - 7622. (e) Braunstein, P. Chem. Rev. 2006, 106, $134-159$.

(4) (a) Braunstein, P.; Knorr, M.; Stern, C. Coord. Chem. Rev. 1998, 178 - 180, 903 - 965. (b) Bader, A.; Lindner, E. Coord. Chem. Rev. 1991, 108, $27-110$.

(5) Espinet, P.; Soulantica, K. Coord. Chem. Rev. 1999, $193-$ $195,499-556$.

(6) (a) Jiménez, M. V.; Pérez-Torrente, J. J.; Bartolomé, M. I.; Gierz, V.; Lahoz, F. J.; Oro, L. A. Organometallics 2008, 27, 224 - 234. (b) Jiménez, M. V.; Rangel-Salas, I. I.; Lahoz, F. J.; Oro, L. A. Organometallics 2008, 27, 4229 4237.

(7) (a) McEwen, W. E.; Smith, J. H.; Woo E. J. J. Am. Chem. Soc. 1980, 102, 2746 - 2751. (b) McEwen, W. E.; Janes, A. B.; Knapczyk, J. W.; Kyllingstad, V. L.; Shiau, W. I.; Shore, S.; Smith J. H. J. Am. Chem. Soc. 1978, 100, $7304-$ 7311.

(8) Anderson, G. K.; Kumar, R. Inorg. Chem. 1984, 23, $4064-$ 4068.

(9) (a) Werner, H.; Hampp, A.; Windmüller, B. J. Organomet. Chem. 1992, 435, 169 - 183. (b) Werner, H.; Hampp, A.;
Peters, K.; Peters, E. M.; Walz L.; von Schnering, H. G. Z. Naturforsch., Teil B, 1990, 45, $1548-1558$.

(10) Unruh, J. D.; Christenson, J. R. J. Mol. Catal. 1982, 14, 19 -34 .

(11) Yamano, M.; Goto, M.; Yamada. M.; Takeda Pharmaceutical Company Ltd. Osaka-shi, Osaka, Japan, EP1626052A1, 2004.

(12) Imamoto, T.; Kikuchi, S. I.; Miura, T.; Wada, Y. Org. Lett. 2001, 3, 87 - 90 .

(13) Brunel, J. M.; Faure, B.; Maffei, M. Coord. Chem. Rev. 1998, $178-180,665-698$.

(14) Lebel, H.; Morin, S.; Paquet, V. Org. Lett. 2003, 5, 2347 2349.

(15) McKinstry, L.; Livinghouse, T. Tetrahedron, 1995, 51, $7655-7666$.

(16) Lindner, E.; Schmid, M.; Wegner, P.; Nachtigal, C.; Steimann, M.; Fawzi, R. Inorg. Chim. Acta. 1999, 296, $103-$ 113.

(17) Holmes-Smith, R. D.; Osei, R. D.; Stobart, S. R. J. Chem. Soc. Perkin Trans. 1 1983, $861-866$.

(18) Struck, R. F.; Shealy, Y. F. J. Med. Chem. 1966, 9, $414-$ 416.

(19) (a) Thapper, A.; Sparr, E.; Jonson, B. F. G.; Lewis, J.; Raithby, P. R.; Nordlander, E. Inorg. Chem. Commun. 2004, 7, 443 - 446. (b) Bassetti, M.; Alvarez, P.; Gimeno, J.; Lastra, E. Organometallics 2004, 23, 5127 - 5134. (c) Barthel-Rosa, L. P.; Maitra, K.; Nelson, J. H. Inorg. Chem. 1998, 37, $633-639$.

(20) Ulmer, L.; Mattay, J.; Torres-García, H. G.; Luftmann, H. Eur. J. Mass Spectrom. 2000, 6, 49-52. 
Graphical abstract

\section{Convenient Methods of Synthesis for a Library of Hemilabile Phosphines}

hemilabile ligands, functionalized phosphines, hydrophosphination

M. Victoria Jiménez,* Jesús J. Pérez-Torrente, M. Isabel Bartolomé and Luis A. Oro

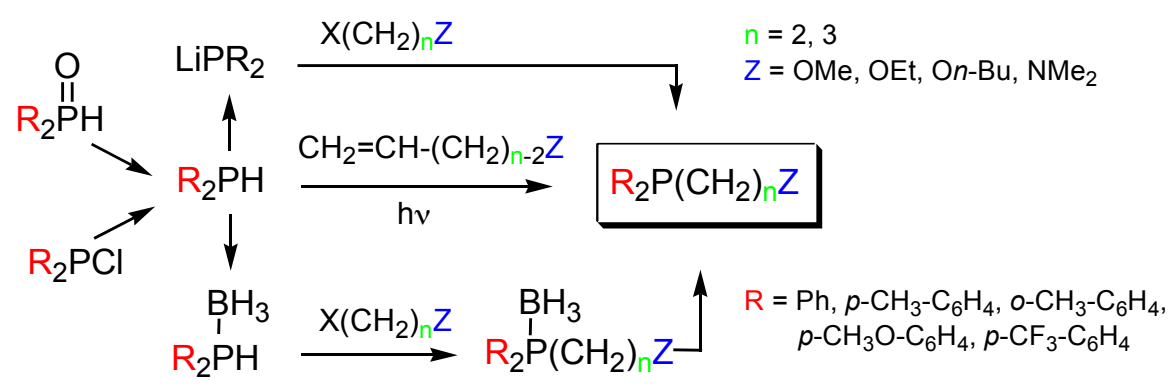

